\title{
STEALING DEPOSITS: \\ DEPOSIT INSURANCE, RISK-TAKING AND \\ THE REMOVAL OF MARKET DISCIPLINE IN \\ EARLY 20TH CENTURY BANKS
}

\author{
Charles W. Calomiris \\ Matthew S. Jaremski \\ Working Paper 22692 \\ http://www.nber.org/papers/w22692
NATIONAL BUREAU OF ECONOMIC RESEARCH
1050 Massachusetts Avenue
Cambridge, MA 02138
September 2016

The authors would like to thank the Gerard Caprio and David Wheelock as well as seminar participants at Columbia University, the Workshop in Macroeconomic Research at Liberal Arts Colleges, the Economic History Association, and the NBER Development of the American Economy meetings for valuable comments and suggestions. The views expressed herein are those of the authors and do not necessarily reflect the views of the National Bureau of Economic Research.

NBER working papers are circulated for discussion and comment purposes. They have not been peer-reviewed or been subject to the review by the NBER Board of Directors that accompanies official NBER publications.

(C) 2016 by Charles W. Calomiris and Matthew S. Jaremski. All rights reserved. Short sections of text, not to exceed two paragraphs, may be quoted without explicit permission provided that full credit, including $\odot$ notice, is given to the source. 
Stealing Deposits: Deposit Insurance, Risk-Taking and the Removal of Market Discipline in Early 20th Century Banks

Charles W. Calomiris and Matthew S. Jaremski

NBER Working Paper No. 22692

September 2016

JEL No. G21,G28,N22

\begin{abstract}
Deposit insurance reduces liquidity risk but it also can increase insolvency risk by encouraging reckless behavior. A handful of U.S. states installed deposit insurance laws before the creation of the FDIC in 1933, and those laws only applied to some depository institutions within those states. These experiments present a unique testing ground for investigating the effect of deposit insurance. We show that deposit insurance increased risk by removing market discipline that had been constraining erstwhile uninsured banks. Taking advantages of the rising world agricultural prices during World War I, insured banks increased their insolvency risk, and competed aggressively for the deposits of uninsured banks operating nearby. When prices fell after the War, the insured systems collapsed and suffered especially high losses.
\end{abstract}

Charles W. Calomiris

Graduate School of Business

Columbia University

3022 Broadway Street, Uris Hall

New York, NY 10027

and NBER

cc374@columbia.edu

Matthew S. Jaremski

Colgate University

Department of Economics

13 Oak Drive

Hamilton, NY 13346

and NBER

mjaremski@colgate.edu 


\section{Introduction}

Deposit insurance spread throughout the world in the latter half of the $20^{\text {th }}$ century as a result of external and internal political pressures favoring its adoption (Demirgüç-Kunt, Kane and Laeven 2008). The International Monetary Fund, the European Union, and the World Bank have all endorsed Deposit Insurance. Despite its overwhelming political support, there is a large empirical literature suggesting that the moral-hazard costs of deposit insurance have out-weighed its liquidity-risk-reduction benefits. ${ }^{1}$ These papers show that deposit insurance is among the most important contributors to the unprecedented waves of banking crises that have washed over the world during the past four decades. The separation between policy recommendations and economic studies begs the question of whether empirical studies may have failed to properly control for the other contributing influences that produced both the rise of deposit insurance and banking instability.

Most studies of deposit insurance are based on cross-country comparisons or comparisons across time within countries that contrast the behavior of insured banking systems with uninsured banking systems. ${ }^{2}$ Despite attempts by authors to control for factors that coincide with the creation or expansion of deposit insurance through explicit controls or through instruments that explain the creation of deposit insurance, it is conceivable that some of the positive association between deposit insurance and increased bank risk may reflect exogenous increases in risk that encourage the passage of deposit insurance. If true, then the risk-creating effects of deposit insurance would be exaggerated.

\footnotetext{
${ }^{1}$ See Brewer (1995), Caprio and Klingebiel (1996), Martinez-Peria and Schmukler (2001), Calomiris and Powell (2001), Demirgüç-Kunt and Detragiache (2002), Honohan and Klingebiel (2003), Demirgüç-Kunt and Huizinga (2004), Cull, Senbet and Sorge (2005), Barth, Caprio and Levine (2006), Demirgüç-Kunt, Kane and Laeven (2008), Beck and Laeven (2008), Laeven and Valencia (2013), Yan et al. (2014), and Calomiris and Chen (2016).

${ }^{2}$ A few exceptions exist. Brewer (1995) achieves identification by comparing the behavior of institutions that had suffered large losses vs. those that had not. Yan et al. (2014) contrast institutions within Australia that were differentially affected by deposit insurance protection. These studies likely suffer less than others from possible endogeneity bias in identifying the effects of deposit insurance.
} 
In this study, we examine a near ideal environment from the standpoint of identification the state deposit insurance experiments of the early 20th century in the United States. ${ }^{3}$ These systems installed deposit insurance for unit state-chartered commercial banks that operated in parallel to the uninsured system of national banks (i.e., unit banks that were chartered by the Comptroller of the Currency) within the same states and to uninsured state and national banks operating in bordering states. Mitigating the omitted variable problem embodied in cross-country studies, the period thus allows for the study of insured and uninsured depository institutions operating at the same time and place as well as under the same legal system, currency, and language. We employ detailed information about the locations, economic environments, and bank-level balance sheet characteristics of insured and uninsured banks for many states and years. Specifically, we implement a difference-in-difference-in-difference model that measures the effect of deposit insurance on insured banks controlling both for the change in uninsured banks in the deposit insurance states and for the change of uninsured banks in other states. Moreover, because several of the laws were passed in the same year but implemented in different subsequent years, we are able to use placebo tests to determine whether a region-specific economic shock was responsible for changes in banks' and depositors' behavior in addition to the passage of deposit insurance, or alternatively, whether changes in behavior were the consequence of deposit insurance.

\footnotetext{
${ }^{3}$ A recent working paper by Aldunate (2015) uses a similar difference-in-difference-in-difference approach to ours but with a smaller sample of banks. Aldunate compares the growth of various bank balance sheet measures (e.g., deposits, loans to assets, investments to assets, cash and due from banks to assets, and capital to assets) at the banklevel within the combination of three state pairs: Nebraska/Colorado, South Dakota/Minnesota, and Mississippi/Alabama. For each pair, the analysis only considers a year before deposit insurance was installed and a year after. The study finds that insured banks saw greater deposit growth but it finds no effect on risk-taking or failure rates. Based on our results from a full set of years and additional states, the small sample could be biasing the results. Also, the choice of states means that the years when deposit insurance is in place are concentrated during the World War I agricultural price spike, preventing the analysis from clearly separating the effect of deposit insurance from the region-wide changes in state bank growth due to WWI. Our study differs from Aldunate in numerous other ways, including how we construct uninsured comparison states and our focus on the timing of deposit insurance's effect.
} 
Our findings not only corroborate the prior literature on the moral hazard consequences of deposit insurance, but also show how the introduction of deposit insurance created systemic risk. We find conclusive evidence that deposit insurance caused risk to increase in the banking system by removing the market discipline that had been constraining uninsured banks' decisionmaking. Depositors applied strict market discipline on uninsured banks when evaluating whether to place their deposits in those banks, but seemingly ignored the financial soundness of insured banks. Insured banks thus were able to use the promise of insurance to compete away deposits from uninsured banks. Because they were constrained only by regulatory standards (i.e., a minimum capital-to-deposits ratio, a minimum reserves-to-deposit ratio, and in some cases, a maximum interest rate paid on deposits) which often proved inadequate to prevent insolvency, insured banks raised their loan-to-asset ratios, reduced their cash reserves, and kept their capital ratios close to the regulatory minimum.

Insured banks seemingly were betting on the permanence of agricultural price increases that had occurred during World War I (WWI), and depositors seemingly believed in the insurance systems' ability to protect them. Deposits flowed most strongly into insured banks located in counties where the price rises had the biggest effect. As banks most often used those deposits to fund new loans, the implementation of deposit insurance thus allowed an asset price bubble to quickly form. When prices reversed in the early 1920s, the insured banking systems collapsed and left depositors with losses. For an analysis of the collapses and large losses of the insured systems, see Goldenweiser et al. (1932), Warburton (1959), Calomiris (1990, 1992), Alston, Grove, and Wheelock (1994), and Rajan and Ramcharan (2014).

The rest of the paper proceeds as follows. Section 2 reviews the details of the early $20^{\text {th }}$ century state-deposit insurance systems and summarizes aggregate data on the changing 
allocation of deposits that accompanied the passage of deposit insurance. Section 3 describes our data set. Section 4 reports our findings on the effects of deposit insurance on insured and uninsured banks' deposits, loans, cash to asset ratios and leverage. Section 5 analyzes the flow of deposits and examines how the relaxation of market discipline from deposit insurance changed the nature of competition in the deposit market. Section 6 discusses the collapses of the insured banking systems during the 1920s. Section 7 concludes.

\section{State Deposit Insurance Schemes of the Early $20^{\text {th }}$ Century}

The United States was a bank liability insurance innovator installing the only deposit insurance systems for nearly 150 years. The unique propensity for liability insurance in the United States reflected political influences that also produced the United States' unique single-office (“unit banking”) system (for a review of the history of liability insurance, see the Online Appendix, under "Historical Background”). While a couple states installed liability insurance funds during the antebellum period, none lasted beyond the Civil War and it was not until the early 1900s that another wave of laws was passed. During the wave, however, eight states passed deposit insurance laws from 1907 to 1917. Each law created a non-state guaranteed fund that would be used to reimburse any deposits in the event of a failed member bank. The laws stipulated each

bank's annual assessment (typical a very small fraction of their deposits minus capital), as well as the maximum extra assessment that each bank could be forced to pay to replenish the fund during an emergency. While the laws typically sought to include national banks in their system, the Supreme Court ruled that national banks were not allowed to join.

The major differences across the deposit insurance systems revolved around whether insurance was mandatory. Kansas and Washington passed voluntary laws that gave state banks 
the choice of whether to opt into the system. Texas allowed banks to opt out of the state's deposit insurance system if they were willing to insure their deposits by posting a collateral bond. South Dakota also passed a voluntary deposit insurance law, but it did not give rise to an insurance system because the creation of the system depended on obtaining a required number of members before it could begin operation. When given a choice, many banks chose not to join the system. At least 35 percent of banks remained outside Kansas' system (Wheelock and Kumbhakar 1995), more than 60 percent of banks remained outside Washington's system (Annual Report of the Bank Commission of the State of Washington 1918-1920), and 9 percent of Texas state banks opted to purchase an insurance bond (Hooks and Robinson 2002).

The laws were geographically concentrated. Figure 1 shows the geographical pattern of insured states and the comparison group of non-insured neighboring states that we will focus on in our analysis. Oklahoma (passed a law in 1907 that took effect in 1908), Texas and Kansas (in 1909), Nebraska (passed a law in 1909 but was not active until a second law was passed in 1911), South Dakota (passed a law in 1909 but was not active until a second law was passed in 1916), and North Dakota (passed in 1917 that took effect in 1918) form a column down the middle of the country. The two geographic outliers (Mississippi in 1914 and Washington in 1917) both seemingly installed their systems as a hasty reaction to bank failures in their state (Robb 1921). As seen in Table 1, Mississippi and Washington were also dissimilar in many respects from the other deposit insurance states.

Small and undiversified banks in rural areas were the main supporters of deposit insurance as they had the most to gain from protection against credit and liquidity risk. Large state banks and national banks in urban areas fought the legislation as they did not want to be responsible for risky agricultural loans. Therefore, as highlighted in Table 1, insurance laws were 
passed in states where small state banks were more plentiful. ${ }^{4}$ White (1981, p. 539) describes that deposit insurance states had "firmly established unit banking within their boundaries and were all in relatively undiversified regions where business prosperity in general depended on one or two commodities.” White's empirical analysis shows that deposit insurance was passed in states with low minimum capital requirements for state banks (or alternatively low average state bank size) and unit banking. The agricultural states in the Midwest and South Central were thus prime candidates for deposit insurance. Indeed, many other states in these regions (e.g., Colorado, Minnesota, and Missouri) narrowly defeated deposit insurance legislation during the period, yet few states outside of these regions even considered or voted upon deposit insurance. (Cooke 1910; White 1981)

\subsection{Analysis of Trends}

To examine the aggregate effects of the various states' legislation, Figure 2 illustrates aggregate deposits separately for early deposit insurance adopters (i.e., Oklahoma, Texas, Kansas, and Nebraska), late deposit insurance adopters (i.e., Mississippi, South Dakota, North Dakota, and Washington), and non-adopters of deposit insurance in the geographic comparison group. The figure shows that deposit insurance states experienced similar growth trends as non-deposit insurance states surrounding the installation date. From 1908 through 1914, deposits grew by 39 percent in the comparison states and by 42 percent in the early adopter states. The only large differential growth between deposit insurance and non-deposit insurance states occurred after 1914. From 1914 through 1919, deposits grew by 90 percent in the comparison states yet by 139 percent in the early adopters. This differential growth coincided with the large increase in crop

\footnotetext{
${ }^{4}$ Some of the geographic similarity among insured state banking systems might also have reflected regulatory competition. For example, Robb (1921, 107-112) describes that Kansas banks along the Oklahoma border pushed for the passage of deposit insurance in order to avoid competition with Oklahoma's insured banks.
} 
prices during World War I. Figure 3 shows that prices almost doubled from 1914 to 1919 under the influence of World War I's contraction in global supply. As Online Appendix Table A.1 shows, farm real estate values also substantially rose and then declined in agricultural states, particularly western states. (Alston, Grove, and Wheelock 1994; Rajan and Ramcharan 2015)

Figure 4 displays the ratio of state bank deposits to national bank deposits (normalized to 1900's value). Unlike the combined national and state bank data, there are clear jumps in state banking relative to national banking surrounding the passage of deposit insurance. State bank deposits jump sharply relative to national bank deposits in 1908 and 1909 for early adopters and display a smaller rise in 1916 and 1917 for late adopters. Between 1907 and 1912, deposits grew 2 percent for the comparison states, yet grew by 31 percent for the early adopters. Between 1913 and 1919, the corresponding numbers would be 9 percent, 22 percent, and 10 percent. The jumps thus correspond to the dates of deposit insurance's passage, and do not seem to be the result of a broader trend. The ratios also clearly illustrate that the boom in agricultural areas during World War I led to the expansion of state banks in all states, but more so in deposit insurance states.

The aggregate data allow us to perform a placebo test to examine whether the factors that led to the law's passage also led to the expansion of state bank deposits or whether it was the actual use of the law that mattered. Nebraska and South Dakota passed deposit insurance laws in 1909 that fell dead on the books. It was not until additional laws were passed in Nebraska in 1911 and in South Dakota in 1915 (and implemented in 1916) that deposit insurance became a reality in those states. If the laws and the bank changes were both the result of some omitted state-level factor, then we would expect to see the growth of banks occur in 1909 in both states. However, if the growth was the result of the implementation of deposit insurance itself, then we should see the growth occur in 1911 for Nebraska and 1916 for South Dakota. Figure 5 shows 
that there was a slight growth in state bank deposits relative to national bank deposits after the passage of the inactive law in South Dakota, but the same pattern is also visible for non-deposit insurance state (growing 10 percent between 1909 and 1910) in Figure 4. There is not a large jump in state bank deposits in deposit insurance states compared to non-deposit insurance states

until after the deposit insurance funds were made active. We conclude that the anticipation of insurance was not enough to spur depositors to move their deposits, and take the figures as evidence that the differential rise in state banks deposits after deposit insurance was not a function of region-wide differential growth.

\section{Data}

We construct two databases to investigate deposit competition and risk attributes of banks before and after enacting deposit insurance. For each database, we restrict the sample to the six states that adopted deposit insurance and the non-deposit insurance states adjacent to them. We do not include Mississippi and Washington for three reasons: (1) they did not provide bank-level information for the entire period, (2) they are geographic outliers that do not fit well with our comparison group of states, and (3) there is evidence that the installation of deposit insurance was a result of an idiosyncratic negative shock.

The first is an annual state-level database that covers all banks and states from 1900 through 1930. The data come from All Bank Statistics and were digitized by Flood (1998). The data provide a separate breakdown of the aggregate balance sheet of all state banks and all national banks in each state. Thus, for each variable of interest, in each year, there are two observations per state, one for state banks and one for national banks. 
The second is a biennial bank-level database from 1900 through 1920. National bank data were published by the Comptroller of the Currency, and state bank data were published separately by each state. While the national bank data are complete for each year and were digitized by Jaremski (2013), many states did not publish state bank data until after 1907 and most only published information every other year (Mitchener and Jaremski 2015). We digitized the data of all states in the sample region that published reports from 1900 through $1920 .^{5}$ As shown in Table 2, missing states are usually in the west (e.g., Arizona and Utah) where banking was still in its infancy. When single year gaps in the data for a particular state exist, we interpolate those state bank values. ${ }^{6}$ Our interpolation method begins with a linear interpolation of each individual state bank's observations, which is the midpoint of the two surrounding years. We then adjust those interpolated values by uniformly shifting all of the values so that the average change for those imputed values is identical to the observed change that year in the aggregate value of that variable for state banks in that state. The resulting biennial database contains 65,730 observations and spans 9,027 state banks and 1,925 national banks. Summary statistics for the main variables of interest are provided in Online Appendix Table A.2.

Historical banking reports did not report income statement information. Nor did they collect information about the interest rates paid on deposits (as discussed more fully in the Online Appendix). Therefore, data on interest rates are unavailable for the period at the banklevel or state-level. We, therefore, cannot calculate profit rates or control for the interest rate provided to depositors.

\footnotetext{
${ }^{5}$ Trimming the sample period does not add a large number of additional states. Only Texas is added if we shorten the sample to 1906 through 1914. As for the other deposit insurance states, Oklahoma does not report until after deposit insurance is installed, Mississippi did not report until 1909, and North Dakota and Washington stopped reporting before deposit insurance was installed.

${ }^{6}$ Out of 65,730 observations used in our sample, 4,447 are interpolated.
} 
We augment the bank balance sheet data in several ways. We employ county-level Census data assembled by Haines (2004), which contain information each for decade. Aggregating counties to their 1900 boundaries, we assume that the census variables grew linearly over time, which permits us to construct annual estimates from the decennial observations. These controls are particularly important due to agricultural expansion during WWI. We also add information on whether a county had a clearinghouse in operation from Jaremski (2015).

\section{The Influence of Deposit Insurance on Bank Growth and Risk-Taking}

In money markets, such as deposits, debtholders not only price risk, but demand a very low level of default risk. Following the theories and empirical evidence of this risk intolerance in uninsured deposit markets, uninsured banks are forced by market discipline to target a low level of default risk on their deposits. So long as insurance protection is regarded as credible, however, insured banks face strong incentives to minimize their capital ratios and maximize their asset risk because doing so allows them to reap a subsidy from an underpriced put option implicit in deposit insurance. In the Online Appendix, we review the theory of how deposit insurance should affect insured banks’ behavior relative to uninsured banks that operate alongside them and develop three key hypotheses. We explore the first two of those hypotheses here.

Hypothesis 1: If insured banks are perceived as enjoying protection from deposit insurance (which fails to charge insurance premiums that fully reflect the risk taken by insured banks), then insured banks should be able to offer more attractive terms to depositors than uninsured banks, and therefore, insured banks should increase their share of deposits relative to uninsured banks. 
Hypothesis 2: Because deposit insurance subsidizes insured banks as an increasing function of their riskiness, insured banks should use their deposits to fund risky lending, and should target a higher level of default risk.

In this section, we test these hypotheses to see whether insured banks increased their share of deposits as a consequence of receiving deposit insurance, whether they used those deposits to fund loans, and whether they targeted a higher level of default risk by maintaining lower ratios of cash to assets and capital to assets. We also test whether the effect of deposit insurance was larger in those areas where risk-taking opportunities were largest.

\subsection{Identifying the Effects of Deposit Insurance on Bank Growth and Risk Taking}

Several identification concerns confront studies of the consequences of enacting deposit insurance for the behavior of banks. These concerns raise questions about whether the observed changes in behavior that coincide with the enactment of insurance reflect causal influences of deposit insurance or mere correlation.

First, deposit insurance states could be structurally different from non-deposit insurance states, and might have had persistently higher deposit growth or risk taking than other states. Second, unobserved idiosyncratic shocks may have occurred only in deposit insurance states around the dates that they enacted deposit insurance. The placebo tests we report in Figure 5 which make use of the delayed implementation of deposit insurance in some states to show that the dates of deposit insurance implementation were the relevant trigger for behavioral change rather than deposit insurance legislation - as well as the wide range of deposit insurance passage dates across time would argue against this concern, but it is still conceivable that observed changes in behavior by insured banks may reflect factors specific to the banking system of those 
states around that time other than deposit insurance. Third, all state-chartered banks in the region could have been growing differentially relative to national banks during the period when deposit insurance was installed. The differences between state and national banks in deposit insurance states after the enactment of deposit insurance thus may simply reflect a continuation of preexisting differences in trends or even a region-wide structural break in the difference between state banks and national banks that happened around the same time as deposit insurance.

In the empirical analysis reported here, we take advantage of the unique structure of deposit insurance laws and the locations of banks operating under different charters and different insurance coverage to directly control for these factors. This approach allows us to overcome the three identification challenges listed above and identify the causal effect of deposit insurance on the outcomes of banks.

First, we show that neither deposit insurance states nor state banks within those states had differential trends in either deposits or loans prior to the passage of the first deposit insurance law in 1908 (Table 3). Second, in the analyses of both state-level aggregates (Table 4) and individual bank behavior (Tables 5 through 8), we measure the effects of deposit insurance while including various economic and demographic characteristics to control for any locational differences that might still remain within the comparison groups. All our panel regressions also include fixed effects to account for any coincidental structural differences across bank charter types (all insured banks were chartered by states, not by the federal government) or exogenous differences in individual bank business models or locations.

To help control for location-specific differences across all banks, we include national banks in insured states (which operated in each state under uniform chartering rules) in the regressions. National banks were present in the same locations as insured state banks yet could 
not join the insurance systems. They thus offer a within-state comparison group. If the passage of deposit insurance happened to coincide with a positive financial shock, then we would expect it to have positively influenced all banks in the state not just insured banks.

To control for locational differences in bank opportunities and risks that were specific to state-chartered banks, we include both insured and uninsured state-chartered banks in the regressions and allow them to exhibit differential behavior after deposit insurance was installed in the state or a neighboring state. This control group is necessary because state-chartered banks were generally permitted greater latitude than national banks to loan against real estate, and typically were subject to less restrictive entry rules and prudential regulations. By including both state and national banks in the regression models, we control for opportunities that were specific to state-chartered banks in the region, as well as locational growth differences that affected both national and state banks in the same locations.

In addition to these standard specifications, we check the robustness of our results with respect to various potential issues. To take account of potential differences across deposit insurance systems and provide a narrower geographic comparison, we also analyze each of the insurance systems one at a time against a comparison group of neighboring banks (Table 7). We find that our results are present in each of the insured states, and we also identify differences in the magnitudes of the effects of insurance that are associated with differences in deposit insurance law (specifically, whether insurance was voluntary or mandatory), We find that voluntary insurance in Kansas was associated with smaller absolute values of insured bank responses than in the involuntary insurance states of Nebraska and South Dakota. In the Online Appendix, we also report the main regression specifications where we drop out populated areas that may have established non-agricultural based-banks (Tables A.3. and A.4). 
In summary, by including all these various controls in the regression specification, we are able to identify the additional effect of deposit insurance over and above any regional state bank growth trends or location-specific growth trends occurring during the period.

We consider four key endogenous variables that respond to deposit insurance: deposits, loans, the capital to assets ratio, and the cash to assets ratio. Deposits measure the ability of the banks to compete for funding. Loans capture the use of deposits to fund loans. The capital ratio and cash ratio negatively affect bank default risk.

Our empirical model is a difference-in-difference-in-difference specification that takes the form of:

$$
\begin{gathered}
Y_{i, s, t}=a+\beta_{1} D I_{s, t}+\beta_{2} D I_{s, t} * \text { Insured }_{i}+\beta_{3} \text { DIArea }_{s, t} * \text { StateBank }_{t}+\beta_{4} X_{i, s, t}+t_{t}+u_{i, s} \\
+e_{i, s, t}
\end{gathered}
$$

where $Y_{i, s, t}$ is the one of the key variables of interest described above for bank $i, D I_{s, t}$ is a dummy variable that takes a value of 1 if deposit insurance was active in the state during the year, StateBank $k_{i}$ is a dummy variable that takes a value of 1 if the observation was from a state bank, DIArea $_{i, t}$ is a dummy variable that takes a value of 1 if the state had deposit insurance active or neighbored a state with deposit insurance active, $X_{i, s, t}$ is a vector of census variables including the logarithm of population, the logarithms of crop and manufacturing output per person, the percent change in crop output, the fraction of population living in a location of 2,500 or more, the number of state banks, the number of national banks, and a dummy variable for whether a clearinghouse was in operation in the local economic environment of the bank, $t_{t}$ is a vector of year fixed effects, $u_{i, s}$ is a vector of bank-fixed effects, and $e_{i, s, t}$ is the error term 
clustered by county. ${ }^{7}$ For the state-level results, $X_{i, s, t}$ does not include the number of banks or the local clearinghouse indicator, $u_{i, s}$ is a vector of state-banktype fixed effects, and the error term is clustered by state. ${ }^{8}$

Putting the model into the context of the identification concerns, the bank-fixed effects control for the possibility that deposit insurance states and state banks in those states were always different. The time-fixed effects capture changes in each year that were common to all banks and thus control for macroeconomic factors and changes in federal regulation. The deposit insurance dummy variable accounts for the effect of the introduction of deposit insurance on all banks in a state relative to banks in non-deposit insurance states. The interaction between the state bank dummy and $D I A r e a_{s, t}$ accounts for the possibility that all state banks started growing differently from national banks around the same time that deposit insurance was installed in their area. Finally, the interaction between the deposit insurance dummy and the insured bank dummy, when controlling for all other influences, captures the causal effect of deposit insurance on insured state banks. When the interactions are excluded, $\beta_{1}$ captures the average partial covariance of deposit insurance with both state and national bank behavior; however, when the interactions are included, $\beta_{2}$ measures the covariance of deposit insurance with bank behavior for state banks in deposit insurance states after controlling for differential growth of all banks in deposit insurance states $\left(\beta_{1}\right)$ and differential state bank growth relative to national banks in nondeposit insurance states $\left(\beta_{3}\right)$. Note that the estimated growth of national banks in deposit insurance states is captured by $\beta_{1}$ whereas the estimated growth of state banks in deposit

\footnotetext{
${ }^{7}$ Some of the control variables in $X_{i, s, t}$ could be endogenous to the passage of insurance. For example, if insurance increased bank lending on risky real estate, then it may have affected crop output. These extra controls, therefore, should produce a more conservative estimate because controlling for such variables reduces the estimated impact of deposit insurance.

${ }^{8}$ We include the number of banks as a dependent variable rather than a control variable in the state-level results as we are interested in the aggregate effect not the effect on the average bank. We do not include the clearinghouse indicator because clearinghouses operated at the city level and nearly every state had a clearinghouse.
} 
insurance states is reflected in the sum, $\beta_{1}+\beta_{2}+\beta_{3}$. The causal effect of deposit insurance coverage on insured banks is captured by $\beta_{2}$.

\subsection{State-Level Pre-Trends}

We begin by examining whether deposit insurance states and state banks in those states were on different trajectories prior to the legislation. The use of difference-in-difference-in-difference modeling assumes that states that installed deposit insurance were on the same trend as other states and in the absence of the legislation they would have continued to be similar. The parallel trends assumption is important to test at the state-level as it is the level of aggregation where the decision was made. We therefore model the trend in deposits and loans from 1900 through 1908 to test whether deposit insurance states and their state banks were on different trends. The model is:

$$
\begin{gathered}
Y_{i, s, t}=a+\beta_{1} \text { DIEver }_{s} * \text { Trend }_{t}+\beta_{2} \text { DIEver }_{s} * \text { StateBank }_{i} * \text { Trend }_{t}+\beta_{3} X_{i, s, t}+t_{t}+u_{i, s} \\
+e_{i, s, t}(2)
\end{gathered}
$$

where $\operatorname{Trend}_{t}$ is a linear trend, DIEver is a dummy variable that takes a value of 1 if the state ever installed deposit insurance, and the rest of the variables retain their prior definitions. Note that when analyzing state-level aggregates, we cannot separate insured state banks and uninsured state banks in Kansas and must analyze the two combined.

We test whether deposit insurance states had different trends before 1908 (i.e., $\beta_{1} \neq 0$ ) and whether state banks in deposit insurance states had different trends than national banks in deposit insurance states before 1908 (i.e., $\beta_{2} \neq 0$ ). The results, reported in Table 3, show no evidence of a differential trend amongst states. None of the interactions are statistically significant, and the standard errors are quite large. 


\subsection{State-Level Model}

Next, we examine aggregate bank behavior at the state-level after the passage of deposit insurance. While bank-level data allow us to more properly control for idiosyncratic differences, the state-level data permit us to analyze the overall effects of deposit insurance on the relative sizes of insured and uninsured banking systems as a whole, including on deposits and loans as well as the number of banks. Because the aggregate state-level data do not distinguish between state banks in Kansas that did and did not join the insurance system, we combine insured and uninsured state banks in Kansas for now. The state-level results, however, are similar when separating the types of systems, albeit with a lower effect for the voluntary system of Kansas. The aggregate state-level results are presented in Table 4. The pattern of coefficients in columns (1) and (3) imply no significant effect from deposit insurance on the number of banks operating in insured states or the total amount of deposits, but the coefficient in column (5) implies that total lending increased substantially in the presence of insurance in a state. When the interactions are included (in columns (2), (4) and (6)), deposit insurance of state banks is associated with an increase in the value of both aggregate deposits and aggregate loans for state banks relative to national banks. The coefficient on the interaction between $D I_{s, t}$ and the state bank dummy is positive, large and statistically significant for both deposits and loans. The coefficient on $D I_{s, t}$ is negative but statistically insignificant, suggesting that some but not all national banks lost deposits and loans due to deposit insurance. Indeed, the national bank aggregates are influenced by the several large state banks that took out a national bank charter rather than joining the insurance system. 
To get a sense of the overall magnitude, we use the estimated coefficients to measure aggregate effects. Between the installation of deposit insurance and 1920, national bank aggregates in a non-deposit insurance state would be expected to have lost 5.4 percent in deposits (column (4)), state bank aggregates in a non-deposit insurance state would be expected to have gained 10.2 percent, and state bank aggregates in a deposit insurance state would be expected to have gained 30 percent (i.e., $-0.054+0.102+0.252$ ). For loans in column (6), the comparable numbers would be -5.4 percent for national banks, 9.2 percent for uninsured state banks, and 35.8 percent for insured state banks (i.e., $-0.054+0.092+0.320$ ) .

We can express these numbers in dollar values using the state-level averages for national banks (\$75 million for deposits and \$58 million for loans) and state banks (\$64 million for deposits and \$56 million for loans) in 1908. In this case, the loss to national bank aggregates was \$4 million in deposits and \$3 million in loans whereas the gains to state bank aggregates were \$19 million for deposits and \$20 million for loans. Therefore even though national banks were larger, the percentage losses were still relatively small compared to the percentage gains at state banks. The results thus support Hypothesis 1.

\subsection{Bank-Level Regression Results}

Employing individual bank-level data substantially improves causal identification of deposit insurance's effects. Not only is the sample size larger, but we are able to control for fixed characteristics of individual banks. Because of the disaggregation in the bank-level analysis, we are also able to better account for local (county-level) characteristics that could influence deposit growth at particular banks. Banks operated from a particular location under "unit” (single-office) banking. We match each bank with its county's demographic and economic characteristics in 
place of state aggregates. We also install additional control variables for local bank competition (using the number of banks in the county) and for local financial development (using a dummy variable denoting whether the county had a clearinghouse association in operation). Moreover, we are able to separate the state banks in Kansas that opted out of the voluntary system from insured banks and use them as an additional comparison group. For Kansas, differencing with respect to the behavior of uninsured state banks controls for any unobserved regulatory or environmental characteristics that could affect the behavior of uninsured and insured Kansas state banks.

\subsubsection{Results for Total Deposits and Loans}

The bank-level results reported in Table 5 are similar to the previous results. In the bank-level results case, there are stronger negative effects to national banks and slightly weaker effects for state banks than the aggregate results reported in Table 4. On average, a national bank in a deposit insurance state, ceteris paribus, was predicted to have lost 13.8 percent of its deposits (column (1)) and 6.5 percent of its loans (column (5)) as the result of the introduction of deposit insurance, whereas an insured state bank was predicted to have gained 30.8 percent more deposits and 24.9 percent more loans.

As before, it is useful to think of the total predicted change in deposits and loans for each group of banks. Between the installation of deposit insurance and 1920, the model predicts that national banks in deposit insurance states would have lost 13.8 percent of deposits, uninsured state banks in non-deposit insurance states would have lost 1.4 percent of deposits, and insured state banks would have gained 15.6 percent (i.e., $-0.138-0.014+0.308)$. The effect on loans is similar with national banks losing 6.5 percent, uninsured state banks gaining 6.8 percent, and 
insured state banks gaining 25.2 percent (i.e., $-0.065+0.068+0.249$ ). Taking the average values for individual state and national banks (see Online Appendix Table A.2), these percentages would imply a loss of $\$ 23,248$ deposits and $\$ 10,356$ loans for every national bank and a gain of $\$ 10,559$ deposits and $\$ 15,226$ loans for every insured state bank. Since the average ratio of state banks to national banks was just under 3 to 1 in the region (see Table 1), the aggregate effect would be a small positive gain for deposits and a larger positive gain for loans. Thus when controlling for local as well as regional economic growth, we confirm Hypothesis 1: insured banks attracted deposits away from uninsured national banks. Moreover, the growth in deposits seems to have led banks to use those deposits to fund loan growth.

To what extent did the gains of deposits and loans for insured banks vary with bank characteristics? ${ }^{9}$ Deposit insurance legislation was advocated by small banks who believed they stood to gain most from its protection (White 1983, Calomiris and White 1994). We interact $D I_{s, t} *$ Insured $_{i}$ with a dummy denoting whether the bank was in the lower quantile of capital for all banks. ${ }^{10}$ We also interact $D I_{s, t} *$ Insured $_{i}$ with a dummy denoting whether the bank appeared in the sample after 1903 to capture whether deposit insurance was particularly helpful in attracting deposits for new banks that lacked reputations. The results in columns (2), (3), (6) and (7) show that small and young state banks benefited the most from deposit insurance legislation. A small insured state bank is estimated to have gained 17.3 percent more deposits and 21.2 percent more loans than a large insured state bank, whereas a young insured state bank

\footnotetext{
${ }^{9}$ In results reported in the Online Appendix and not discussed in detail here, we consider whether observable crosssectional differences in the initial health of banks mattered for the magnitude of their responses to deposit insurance. Online Appendix Table A.5 shows insignificant differences related to initial capital ratios of state-chartered banks in states that adopted insurance for all variables but deposits. We show that the absence of a significant cross-sectional difference based on initial bank strength may reflect the ability of strong banks to opt out of the insured system by converting to national bank charters, or (in Kansas) to choose uninsured status as a state bank.

${ }^{10}$ This cutoff is $\$ 16,000$. Since national banks were required to have at least $\$ 25,000$ in capital, the definition excludes all national banks and thus Table 5 does not include an interaction of DI Active In State *Small bank as a control.
} 
gained an additional 6.1 percent more deposits and 6.3 percent more loans than an old insured state bank. As columns (3) and (7) show, when assessing the effect of bank size, it is important to control for the fact that young banks of all kinds tend to have higher growth rates. Young national banks in insured states saw deposit growth that was 29.5 percent higher than for older national banks.

\subsubsection{Riding the Agricultural Price Bubble of World War I}

The final columns of Table 5 examine whether the effects of deposit insurance on deposits and loans may have depended on the local economic environment. In particular, the ability of banks to grow their loans and their risk may have depended on the existence of risk-taking opportunities. The historical narrative of these state deposit insurance systems has emphasized that insured banks funded loans to expand cultivation of crops that were experiencing a World War I-induced priced boom. The local crop mix, therefore, implied different risk opportunities across locations. In areas with crops that were experiencing the World War I-induced price increase, there was ample opportunity to take risk because the expansion of cultivation was risky, given the likely relative decline in prices that would follow the end of the War (which, when it did occur, proved disastrous for banks involved in agricultural lending to affected farmers). To generate a realistic measure of the local effect of the war on banks, we create a measure of local crop value change at the county level. To do so, we first construct a measure of local crop mix based on crop production numbers of each crop in 1910 using Haines (2013). We then create an annual measure of crop value change per capita at the county level (Crop Value) by applying the price of each crop each year in aggregate (from Carter et al. 2006) to that county-level crop mix. The variable captures only the cross-sectional differences among counties in their risk 
environment; year effects remove the average effect of the World War I price run-up (below we show that the World War I period had no differential effect upon all insured banks, per se). Columns (4) and (8) show that the local risk environment mattered for the deposit and loan growth of insured banks. In other words, consistent with the historical narrative, insured banks were riding the crop price bubble of World War I. Not only are the interactions positive and significant for both loans and deposits, but they also account for a large proportion of the overall effect of deposit insurance. Comparing columns (1) and (4), the coefficient on $D I_{s, t} *$ Insured $_{i}$ falls from 0.308 and a p-value under 0.001 to only 0.109 and p-value of 0.210 . In other words, most of the effect of deposit insurance on loan and deposit growth is traceable to the behavior of insured banks in counties that were experiencing an agricultural price boom.

In results reported in the Online Appendix Table A.6 when we constrain the sample period to exclude World War I, we find that the average effect of deposit insurance on deposits and loans, respectively, is 0.204 and 0.157 compared to 0.308 and 0.249 in Table 5. When Crop Value is included in these regressions, the coefficient on $D I_{s, t} *$ Insured $_{i}$ for deposits and loans is roughly half the size of those reported in Table 5, and is no longer statistically significant. These results confirm the previous findings that much, but not all, of the influence of deposit insurance on deposit and loan growth reflected responses to the World War I price run up.

\subsubsection{Results for Risk Variables}

The bank-level results strongly support Hypothesis 1's claim that insured banks competed away the depositors of other systems, but did they also take on more risk (Hypothesis 2). The growth of loans is suggestive of greater loan risk, but not conclusive. Risk is not a simple function of loan growth, but it depends on the (unobserved) riskiness of borrowers, on the 
composition of the asset portfolio (e.g., the ratio of cash assets to total assets), and on bank leverage (i.e., the ratio of capital to assets). We therefore examine how banks' balance sheet ratios changed once they became covered by insurance. We examine cash relative to assets and capital relative to assets. Higher cash to assets reduces insolvency risk by reducing the riskiness of assets and the illiquidity risk of the bank. Higher capital to assets reduces insolvency risk by increasing the capital buffer of junior equity claims (relative to bank debt) that can absorb losses.

The results in Table 6 confirm Hypothesis 2: the installation of deposit insurance encouraged insured banks to take more risk. Insured state banks increased their leverage (i.e., lowered the capital to asset ratio), and reduced the proportion of cash holdings in assets. Specifically, an insured bank is found to decrease its cash to assets ratio by 3.5 percent and its capital to assets ratio by 2.6 percent. At the same time, the effect on national banks is positive in both cases. The typical national bank operating in a state with deposit insurance increased its cash to assets ratio by 4.2 percent and their capital ratio by 2.1 percent. This pattern may reflect rising riskiness of lending during the period: consistent with our theoretical model, national banks targeting a constant level of default risk would have had to respond to rising risk by raising the proportion of cash to assets and reducing leverage.

Similar to our discussion of the effects of deposit insurance on deposit and loan growth, we also consider whether risk increases for insured banks depended on bank age, bank size, and the risk opportunities in the local economic environment. We find that young and small insured banks were much more likely to decrease their cash and capital ratios. Specifically a young insured state bank would have decreased its cash to assets ratio by an additional 1.3 percent and its capital to assets ratio by an additional 1.6 percent after controlling for growth in national banks in its own state and the growth in uninsured state banks in other states. 
As in Table 5, insured state banks in counties with high crop value changes saw the biggest decreases in cash and capital ratios. In columns (4) and (8) of Table 6, the presence of the additional interaction of deposit insurance membership and Crop Value reduces the two ratios so much that it accounts for the entirety of the effect of deposit insurance. The inclusion of this interaction in column (4) even causes the simple average effect of deposit insurance on the cash ratio to flip in sign, indicating that the Crop Value interactions accounts for 200 percent of the average effect.

Clearly, insured banks were expanding their risk very much as part of the risk-taking process of the agricultural boom in crop prices. As suggested by Rajan and Ramcharan (2015), the installation of deposit insurance, therefore, likely helped to magnify the investment bubble that developed in the late 1910s. This result is significant in light of the subsequent agricultural price collapse, and the disruption to the banking system and the local economies that it produced, which we discuss in Section 6.

When we limit the sample to the pre-World War I period (reported in Online Appendix Table A.7), we find that the average effect of deposit insurance on the ratio of cash to assets and the ratio of capital to assets, respectively, are smaller than those in Table 6, but remain statistically significant in the pre-World War I sample. The ratio of cash to assets is -0.004 compared to -0.035 , and the ratio of capital to assets is -0.022 compared to -0.026 . When Crop Value is included in the regressions, the coefficient on $D I_{s, t} * \operatorname{Insured}_{i}$ becomes small and statistically insignificant. These results confirm the findings of Table 6 that much, but not all, of the influence of deposit insurance on deposit and loan growth reflected responses to the World War I price run up. 


\subsubsection{Border Sample Specifications}

The conclusions drawn from the difference-in difference-in-difference regressions based on the full sample of banks from the comparison region (which consists of national banks, insured state banks, and uninsured state banks in several western states) are dependent upon comparability of the banks in the sample. Although we believe that assumption is reasonable given the proximity of these locations to one another, their similar dependence on agriculture, and the use of countylevel controls and bank and year fixed effects in our estimation, here we consider a narrower sample on which to base our comparisons. In results reported in Online Appendix Tables A.9 and A.10, we include only banks located in counties along the border between a deposit insurance state and a non-deposit insurance state. We assume that it is very unlikely that any economic or environmental factors that affect one side of the border do not affect the other side of the border. The coefficients on DI Active in State * Insured are not statistically significantly different from those in Tables 5 and 6. We conclude that restricting comparisons has little effect on our results, which implies that banks throughout the comparison states operated in similar economic environments.

\subsubsection{Voluntary vs. Mandatory Insurance}

Previous studies of these state deposit insurance experiments have argued that the incentive effects of deposit insurance systems should be mitigated when the system is voluntary (Calomiris 1989, 1990, 1992). When deposit insurance is voluntary, large, low-risk statechartered banks can opt out of the system without converting to a national bank charter. Thus, in voluntary deposit insurance systems, where cross-subsidization of risk within the system was 
limited by the greater ability of large established banks to opt out of membership in the insurance system, the incentive effects of deposit insurance for risk taking may have been mitigated.

To investigate this possibility, we divide the sample into three groups based on the three deposit insurance systems and their closest uninsured neighbor. Kansas is the only voluntary system in our sample. In the analysis of Kansas, we include only insured and uninsured state banks located in the state. ${ }^{11}$ For the compulsory insurance system of Nebraska, we include state and national banks in Nebraska as well as state and national banks located in Iowa. For the compulsory system of South Dakota, we similarly include state and national banks in South Dakota, as well as state and national banks located in Minnesota and Montana.

The results in Table 7 confirm the hypothesis that voluntary insurance somewhat mitigated the incentive consequences of deposit insurance for all four endogenous variables. In columns (2) and (3), the absolute value of the coefficient of DI Active in State * Insured for loans and the cash to assets ratio for Kansas are lower than either of the coefficients for Nebraska and South Dakota. In columns (1) and (4), the absolute value of the coefficient on DI Active in State * Insured is lower in Kansas than in South Dakota, and is slightly higher in Kansas than in Nebraska. In the cases where the coefficient on DI Active in State * Insured for Kansas is greater in absolute value than the comparable coefficient for Nebraska, it is never statistically significantly different.

In Online Appendix Table A.13, we aggregate the three separate analyses reported in Table 7 into a single specification, where the responses associated with the two mandatory insurance systems (Nebraska and South Dakota) are constrained to be equal. This permits a formal test to see whether, on average, voluntary insurance differs in its consequences from

\footnotetext{
${ }^{11}$ The results are similar if national banks in Kansas are also included. These specifications are provided in Table A.11 and A.12 in the Online Appendix.
} 
mandatory insurance. The absolute values of the estimated effects of insurance are greater for mandatory insurance for all four dependent variables, and are statistically significant at the 1 percent level for all but the capital to assets ratio.

\subsubsection{Adjusting to Deposit Insurance}

Our analysis thus far has assumed that once deposit insurance was enacted it had its full effects immediately. In reality, it may have taken time for banks and their customers to react to the passage of deposit insurance. Because deposit insurance was passed at different dates in all three of our sample states, we are able to estimate the adjustment process separately from the influence of common time fixed effects.

We augment the model by looking at the effect of deposit insurance in the first biennial period, the second biennial period, and so on. The model takes the form:

$$
\begin{gathered}
Y_{i, s, t}=a+\sum_{\gamma=1}^{4} \beta_{\gamma} \operatorname{DIYr}_{s, t}+\sum_{\gamma=1}^{4} \beta_{\gamma+4} \operatorname{DIYr}_{s, t} * \text { Insured }_{i}+\beta_{9} \text { DIArea }_{s, t} * \text { StateBank }_{t} \\
+\beta_{10} X_{i, s, t}+t_{t}+u_{i, s}+e_{i, s, t} \text { (3) }
\end{gathered}
$$

where $D I Y r \gamma_{s, t}$ is an indicator if deposit insurance was in its $\gamma t h$ biennial period in the state and the rest of the variables take their previous values.

Table 8 reports the coefficients for equation (3) for each of the four dependent variables (deposits, loans, the cash to assets ratio, and the capital to assets ratio). With respect to the behavior of insured banks, the coefficients on DI Active in State * Insured for each year after enactment of deposit insurance indicate that there is a large immediate effect of deposit insurance for every variable. All four variables, however, show increasing absolute values of the effects of deposit insurance over time (although the cash ratio does not change uniformly over time). 
We push the model a step further to examine the role of the World War I agricultural price boom in more detail. In the presence of the variables controlling for dynamic adjustment, we can better gauge the effects of the price boom. In columns (2), (5), (8) and (11) of Table 8, we examine whether there is an average time effect of World War I on all insured banks. This is captured by the coefficient on DI Active in State * Insured * WWI Period. Here, WWI Period is 1916 and 1918. Interestingly, in three of the four cases (columns (2), (5) and (11)), there is no observed average effect of deposit insurance across all insured banks that is specific to the World War I period. That said, the previous specifications have suggested that the price increased helped certain areas more than others. We, therefore, in columns (3), (6), (9) and (12) include DI Active in State * Insured * Crop Value in lieu of DI Active in State * Insured * WWI Period. In three of the four regressions, this variable continues to be large and statistically significant, which echoes the results reported in Tables 5 and 6 . Overall, this confirms the view that the price run-up of World War I magnified the incentive effects of deposit insurance primarily for banks that were located in counties experiencing pronounced price increase. Additionally, the War had a greater effect on all banks operating within insured states, whether or not they were insured banks. The significance of that effect highlights the importance of the inclusion of a rich set of controls in the regressions, especially local risk-taking opportunities.

\section{Competing for Deposits: Does Deposit Insurance Remove Market Discipline?}

Here we model competition in the market for deposits, where the flow of deposits is the key dependent variable of interest. In the theory reviewed in the Online Appendix, the relationship between deposit flows and bank risk characteristics should differ for insured and uninsured banks. Hypothesis 3 states that the installation of deposit insurance created two classes of banks: 
disciplined (uninsured) and undisciplined (insured). Insured banks that took more risk were not disciplined by depositors because many depositors perceived that the deposit insurance system was credible. Insured banks were able to offer high interest rates because of their greater lending risks and higher loan interest rates, while deposit insurance protection limited the perceived riskiness of their deposit accounts. In contrast, uninsured banks lost deposits to insured banks because their low required risk level prevented them from competing for deposits by offering high interest rates. Uninsured banks competed with one another for deposits based on their ability to demonstrate to the market that their risk was sufficiently low using observable fundamentals, including their leverage, loans to assets ratio, and observable loan risk.

We test this model of deposit competition by examining the response of depositors to balance sheet characteristics of insured and uninsured banks that should have mattered for deposit risk. Following our theoretical framework, we model the flow of deposits as reacting to the previous value of the bank's risk characteristics, which include the loan to asset ratio and the capital to asset ratio. We also include real estate owned relative to assets as a measure of loan portfolio risk. ${ }^{12}$ Economic theory and several empirical studies have shown that deposit flows of uninsured banks will respond positively to the capital ratio and negatively to the loan to asset ratio and to measures of loan portfolio risk (Martinez-Peria and Schmukler 2001, Calomiris and Powell 2001). Once deposit insurance is active, we expect that the coefficients on each of these three variables will be reduced in absolute value only for insured banks.

The regression model is a reduced form forecasting model of deposit flows. Depositors control the change in deposits, which respond with a lag to the lending and risk management

\footnotetext{
${ }^{12}$ This variable was used by studies such as Calomiris and Mason $(1997,2003)$. Real estate owned contains foreclosed properties, and thus is a proxy of previous loan failures. The historical banking reports do not include information on income or asset quality, preventing the use of direct measures of risk such as loan losses or nonperforming assets.
} 
decisions of banks, and bank behavioral choices result in cross-sectional differences in three key variables. ${ }^{13}$ Because national banks were historically less likely to fail than state banks and the Comptroller of the Currency did not report real estate owned for much of the period, we exclude them from the analysis to avoid having to take into account two different target levels of risk for uninsured state and national banks. We estimate the model as a single panel from 1900 through 1920 (Table 9 and 11) and as individual biennial cross-sections (Tables 10 and 11). Doing so permits us to investigate whether depositor behavior differed across periods. The panel model is:

$$
\Delta D_{i, s, t}=a+\beta_{1} D I_{s, t}+\beta_{2} Y_{i, s, t-2}+\beta_{3} Y_{i, s, t-2} * \operatorname{Insured}_{i, s, t}+\beta_{4} X_{i, s, t}+t_{t}+u_{i, s}+e_{i, s, t}
$$

where $Y_{i, t-2}$ is a vector of the balance sheet ratios described above in the previous period (i.e., two years before) and all the other variables retain their definitions. The cross-sectional model is:

$$
\Delta D_{i, s}=a+\beta_{1} Y_{i, s, t-2}+\beta_{2} Y_{i, s, t-2} * \text { Insured }_{i, s}+\beta_{3} X_{i, s}+s_{s}+e_{i, s}
$$

where $s_{s}$ is a vector of state fixed effects and the rest of the variables retain their definitions.

The first column of Table 9 shows the panel results for our model. For illustrative purposes, in columns (2)-(4), we report estimates that include only one of the three risk measures in the model. The sign on the real estate owned ratio is negative in the presence of all three risk measures, indicating that ceteris paribus, higher loan risk produces deposit outflow. However, the sign on the real estate owned ratio is positive in the absence of the other two variables. This reflects the high covariance between loan risk and the other two risk measures: banks with very risky lending portfolios tend to maintain lower loan ratios and higher capital ratios. If not, then uninsured banks with high levels of real estate owned would not have gained deposits.

The results confirm Hypothesis 3. In the absence of deposit insurance, depositors disciplined banks. The loans to assets and real estate to assets ratios negatively predict deposit

\footnotetext{
${ }^{13}$ In theory, banks could respond to losses by reducing dividend payout or raising new shares, but studies have shown that banker responses to shocks often take the form of loan reductions (e.g., Calomiris and Wilson 2004).
} 
growth while the capital to assets ratio positively predicts deposit growth. However, once deposit insurance was in place, insured banks' risk characteristics became much less relevant to their ability to attract deposits. The coefficients of the three risk characteristics interacted with the presence of deposit insurance have opposite signs to the coefficient values for insured banks. The summing of the three sets of coefficients for insured banks indicate a near zero effect of these risk characteristics for insured deposit flows. Only the capital to assets ratio remains significantly above zero. Simply put, insured depositors disregarded the typical warning signs of increasing failure risk for insured banks.

The cross-section results in Table 10 show that the removal of discipline occurred primarily during the WWI period. That is consistent with our discussion of Tables 5, 6, and 8, where we find that the incentive effects of deposit insurance were primarily visible in counties experiencing large increases in crop value, which occurred during World War I. The coefficient on the deposit insurance interaction is only positive and significant for the loan ratio after 1914. The coefficient on the interaction of real estate owned and deposit insurance is positive and significant only for 1916 through 1920. The coefficient on the interaction of deposit insurance and the capital ratio is only significantly negative from 1914 through 1920 . The largest coefficients on the interactions appear in 1916 when commodity prices were taking off. In other words, depositors were ignoring the warning signs of insured banks specifically when those banks were making very risky bets about the persistence of the World War I price increases.

Table 11 provides further information on deposit flows, taking into account differences in individual state insurance systems. Recall that states differed with respect to whether their systems were voluntary or mandatory. Table 11 breaks out the discipline effects separately for Kansas, Nebraska, and South Dakota. The interactions of the three risk measures with the 
presence of involuntary deposit insurance systems are large in absolute value for all three measures during the World War I era. The voluntary system in Kansas displays somewhat weaker effects on the interactions for two of the three risk measures, but not for the capital ratio.

\section{When the Bubble Collapsed}

Our analysis of the effects of deposit insurance on bank risk taking showed that insured banks rode the asset price bubble that formed as a result of World War I. What happened once prices collapsed after 1920? It is conceivable that deposit insurance could have helped cushion the state banking system during the downturn by mitigating depositors' incentives to run on banks. Alternatively, deposit insurance may have exacerbated the collapse. Deposit insurance allowed banks to take on greater risk, and once depositors realized the implications of agricultural price collapses for the insurance fund, the resulting collapse of confidence may have hastened depositor runs. Recall that the credibility of deposit insurance could be called into question because the funds were not state guaranteed. A sufficiently large shock to the system could (and did) result in a failure to cover insured deposits.

\subsection{The Flight from the Insurance Systems}

The existing literature clearly shows that deposit insurance did not shield the systems from runs and collapses. All of the deposit insurance systems suspended during the 1920s, and all but the voluntary Texas system resulted in depositor losses. Calomiris (1992) find that deposit insurance states worsened the contraction of deposits during the 1920s and the magnitude of losses to depositors. Wheelock and Wilson (1995) show that insured state banks failed much more often than uninsured state banks in Kansas during the downturn, Hooks and Robinson (2002) shows a 
higher failure rate of insured banks in Texas, and Alston, Grove, and Wheelock (1992) show that the agricultural downturn caused more rural bank failures in deposit insurance states. A study of bank behavior during the downturn by Wheelock and Kumbhakar (1994) also shows that insured banks continued to maintain their risky portfolio distributions even in the face of failures. Although Chung and Richardson (2006) do not find a connection between greater bank suspensions and deposit insurance during these banking system collapses, they do find an unusually large rise in the number of suspensions caused by mismanagement before the collapse relative to other states.

Scholars of the period point to the high risk taking, low amount of supervision, and low assessment rates of the deposit insurance systems as key factors in promoting large losses. None of the scholarship analyzing the collapses of deposit insurance systems credits deposit insurance with having limited runs on banks during the price collapse. For instance, Warburton (1959, p. 31-33) writes about Oklahoma’s collapse: “In the latter part of 1920 and in 1921 came the nationwide wave of bank failures accompanying the deflationary policies of that period. The impact of the deflation on banks in Oklahoma was doubtless accentuated by the laxity of bank supervision after 1919 but the major factor in the situation was the collapse in values, particularly in farm products...With numerous additional failures in 1922, and a sharp contraction of deposits in participating banks and therefore in the income from assessments, there was no hope of restoring the system to solvency." Similar events played out in the other deposit insurance states. Even a few failures put severe pressure on the already notoriously small insurance funds. The insured systems lacked the ability to quickly replenish the fund should the need arise. The funds often issued warrants on future assessments to stave off bankruptcy, but 
this just kicked the can down the road. As losses mounted and the probability of a bailout declined, it became obvious the systems would fail.

As price collapses and bank failures put pressure on the deposit insurance systems, solvent banks quickly abandoned them. Banks in both voluntary and involuntary deposit insurance system could have avoided being subject to insurance and assessments by adopting a national bank charter. As we show in Table 12, despite having about the same number of state banks as neighboring states on average during the period, deposit insurance states saw a much higher number of national bank conversions than nearby states. ${ }^{14}$ The ratio of converting banks to remaining state banks was significantly larger in deposit insurance states than neighboring states before the collapse of the deposit insurance systems, and the difference grew to almost eight times larger after the collapse began. ${ }^{15}$ The ratio of the average capital in converted banks to the average capital in remaining state banks also was much larger in deposit insurance states than in the comparison states. Even in Kansas, where state banks could opt out of the system and retain their state charter, the rate of conversions to national banks and their relative size was still larger than the averages for the comparison states. Since premium payments into the insurance systems were based on either the size of deposits or capital, the removal of these large and likely low-risk banks from the insured systems was a major blow to the prospects of the deposit insurance funds to raise future funds to cover losses.

Comparing state banks that opted out of the Kansas insurance system but did not take a national bank charter against state banks that opted into the system yields similar results. Banks

\footnotetext{
${ }^{14}$ Most states did not report which banks converted to a national bank. We thus cannot examine the characteristics of each individual bank that converted and must make use of the only consistent source of data for the period. Wheelock (1993) finds similar results for the 1920s conversion rates even controlling for a variety of other factors. ${ }^{15}$ The unique presence of St. Louis (which created much larger banks) in Missouri makes it an unsuitable comparison state for this analysis. For example, one St. Louis bank conversion alone in 1919 had capital of \$2.5 million.
} 
that opted out had higher capital to asset ratios (25.10 vs. 22.45 percent) and lower assets sizes (\$132, 518 vs. $\$ 150,528$ ) than those opting in as of 1908. Moreover, the data show that these differences grew over time. By 1920, the differences between the two groups had nearly doubled for the capital ratio (16.95 vs. 12.95 percent) and increased tenfold for assets (\$280,641 vs. \$389, 416). Apparently, relatively safe and stable banks were the ones that opted out of the system.

\subsection{Empirical Analysis of the Collapses of the Deposit Insurance Systems}

To analyze the collapse of the deposit insurance systems, we return to the state-level aggregate data for national and state banks. These data stretch through the 1920s for every year and state. Individual bank data are generally not available during this period. ${ }^{16}$ We examine the effect of deposit insurance over time in each year after it was passed. This amounts to interacting $D I_{s, t}, D I_{s, t} *$ Insured $_{i}$, and Post ${ }_{i, t} *$ StateBank $_{t}$ with a vector of year fixed effects for each year from 1908 through 1930. The coefficients for each year then provide an estimate of the effect of deposit insurance on all banks, the effect of deposit insurance on insured state banks, and the average growth of state banks relative to national banks in all states. As we are interested in tracking the consequences of deposit insurance during the collapse, our deposit insurance indicator variable $D I_{s, t}$ retains its value of “ 1 ” even after a deposit insurance system collapses.

$$
\begin{aligned}
& Y_{i, s, t}=a+\beta_{1} D I_{s, t} * t_{t}+\beta_{2} D I_{s, t} * \text { Insured }_{i} * t_{t}+\beta_{3} \text { DIArea }_{s, t} * \text { StateBank }_{t} * t_{t}+ \\
& \beta_{4} X_{i, s, t}+t_{t}+u_{i, s}+e_{i, s, t}(6)
\end{aligned}
$$

where the variables retain their previous definitions.

\footnotetext{
${ }^{16}$ Many of the states stopped reporting data or reduced the scope of the data during the 1920s.
} 
Because of the large number of estimated coefficients, we display the results of equation (6) in Figure $6 .{ }^{17}$ The top panel contains the coefficients for deposits and the bottom panel contains the coefficients for loans. We calculate the total effect of deposit insurance on insured banks (i.e., $\beta_{1}+\beta_{2}+\beta_{3}$ ). The results are quite clear. Outside of the initial large effect in 1909, the effect of deposit insurance on deposits and loans is greatest during the WWI price increase. While uninsured state bank deposits also rise over the WWI period, uninsured state bank loans do not experience much of an increase. This is consistent with our findings that insured state banks rode the World War I agricultural price bubble more than uninsured state banks, especially for loans.

After 1920, there was a massive decline in insured state bank deposits and loans and a much less dramatic decline for uninsured state banks. Indeed, the coefficients on uninsured state banks largely stabilized by 1924 while the coefficients on insured state banks continue to drop. The difference-in-difference-in-difference coefficient becomes zero in 1922, and is negative by 1926. In summary, the figures show insured state banks saw much larger gains in deposits and loans during the WWI bubble and much greater declines afterwards. We, therefore, conclude that the deposit insurance systems did not cushion their banks during the post-World War I downturn.

\section{Conclusion}

Deposit insurance systems were associated with unusually high rates of expansion during the early twentieth century, and especially during World War I. They were also associated with unusually high bank losses after World War I.

\footnotetext{
${ }^{17}$ While the deposit insurance interactions for loans are almost all statistically significant before 1922, several of the interactions are not statistically significant for deposits. However, the total effect on insured state banks is generally statistically significantly different from zero until 1922.
} 
We are able to identify clearly the role of deposit insurance on depositor and banker behavior because we can compare the behavior of insured and uninsured banks located in the same states as well as banks in neighboring states. We do so first through state-level aggregate comparisons, which track the overall shifts in resources between the two systems within each state, and through panel analyses of individual banks (where we focus on within-bank changes in behavior associated with the passage of deposit insurance).

First, we are able to show that deposit insurance increased insured banks’ deposits and loans, and lowered their cash to asset ratios and capital to asset ratios. Second, we find that deposits flowed from relatively stable banks to risky banks. Deposit insurance increased risk by removing the market discipline in the deposit market that had been constraining erstwhile uninsured banks. Depositors apparently believed that insurance protection was credible and, therefore, were willing to move deposits to banks despite their observably high risk characteristics. Deposit insurance encouraged banks to increase their insolvency risk because doing so did not prevent them from competing aggressively for the deposits of uninsured banks operating nearby. In fact, increasing risk was necessary to fund the higher interest payments that presumably attracted depositors.

The extent to which insured banks attracted deposits away from uninsured banks, and used those funds to expand their lending, depended on the risk opportunities available in their local economic environment. Variation across in counties in the extent to which they produced commodities that appreciated during the World War I agricultural price boom explains between one-third and two-thirds of the observed effects of deposit insurance on deposit growth, loan growth and increased risk taking by insured banks. The fact that a large part of the moral hazard associated with deposit insurance is dependent on the time-varying and location-specific 
opportunities for risk taking has important implications for empirical analysis of the consequences of deposit insurance in other contexts. The potential costs of deposit insurance may appear low in environments that are relatively lacking in risk-taking opportunities, but those costs can appear much higher when greater risk taking opportunities present themselves.

Voluntary insurance systems created weaker subsidies for risk taking by insured banks than mandatory insurance systems. We find that the effects of deposit insurance on our key endogenous variables were mitigated in Kansas (a voluntary insurance state) in comparison to compulsory insurance states.

Insured banks suffered much higher failure rates at the end of World War I, and the collapse of these insurance systems resulted in losses to depositors in all but one of the states. The history of deposit insurance in the United States and internationally has been a process of increasing systemic risk in the name of reducing systemic risk. The deeper lesson of that history is that economic models that attempt to explain the attraction of deposit insurance are less relevant than political ones (Demirgüç-Kunt, Kane and Laeven 2008; Calomiris 2010, Calomiris and Haber 2014; Calomiris and Jaremski 2016). 


\section{Works Cited}

Aldunate, Felipe. 2015. "Deposit Insurance, Bank Risk Taking and Failures: Evidence From Early 20h Century State Deposit Insurance Systems". Unpublished working paper.

Alston, Lee, Wayne A. Grove, and David C. Wheelock. 1994. "Why Do Banks Fail? Evidence from the 1920s.” Explorations in Economic History 31: 409-431.

Barth, James R., Gerard Caprio, and Ross Levine. 1998. "Financial regulation and performance: cross-country evidence." World Bank Policy Research Working Paper 2037.

Barth, James R., Gerard Caprio, and Ross Levine. 2006. Rethinking Bank Supervision and Regulation: Until Angels Govern.

Beck, Thorsten, and Luc Laeven. 2008. Deposit insurance and bank failure resolution: Cross country evidence,” in Deposit Insurance Around the World: Issues of Design and Implementation, edited by A. Demirguc-Kunt, E. Kane, and L. Laeven, 149-78. Cambridge, MA: MIT Press.

Bordo, Michael D. 1985. "The Impact and International Transmission of Financial Crises: Some Historical Evidence, 1870-1933." Revista Di Storia Economica, Second Series 2: 41-78.

Bordo, Michael D. and David C. Wheelock. 2013. "The Promise and Performance of the Federal Reserve as Lender of Last Resort 1914-1933." In The Origins, History, and Future of the Federal Reserve: A Return to Jekyll Island, edited by Michael D. Bordo and William Roberds, Cambridge University Press, 59-98.

Brewer III, Elijah. 1995. "The impact of deposit insurance on S\&L shareholders' risk/return trade-offs." Journal of Financial Services Research 9.1: 65-89.

Calomiris, Charles W. 1989. "Deposit insurance: lessons from the record." Economic Perspectives 13.3: 10-30.

Calomiris, Charles W. 1990. "Is Deposit Insurance Necessary? A Historical Perspective.” Journal of Economic History 50, 283-295.

Calomiris, Charles W. 1992. "Do vulnerable economies need deposit insurance." If Texas Were Chile, A Primer on Banking Reform. San Francisco: Sequoia Institute: 237-314.

Calomiris, Charles W. 2010. "The political lessons of Depression-era banking reform." Oxford Review of Economic Policy 26.3: 540-560.

Calomiris, Charles W. and Mark A. Carlson. 2016a. "Corporate governance and risk management at unprotected banks: National banks in the 1890s.” Journal of Financial Economics forthcoming.

Calomiris, Charles W. and Mark A. Carlson. 2016b. "Interbank networks in the national banking era: their purpose and their role in the panic of 1893." Unpublished Working Paper.

Calomiris, Charles W. and Sophia Chen. 2016. "The spread of deposit insurance and the global rise in bank leverage since the 1970s.” Working paper.

Calomiris, Charles W. and Gary Gorton. 1991. "The origins of banking panics: models, facts, and bank regulation." In Financial markets and financial crises, edited by R. Glenn Hubbard. Chicago: University of Chicago Press, pp. 109-174.

Calomiris, Charles W. and Stephen H. Haber. 2014. Fragile by design: The political origin of banking crises and scarce credit. The Princeton Economic History of the Western World, Joel Mokyr, Series Editor.

Calomiris, Charles W., Charles P. Himmelberg, and Paul Wachtel. 1995. "Commercial paper, corporate finance, and the business cycle: a microeconomic perspective." CarnegieRochester Conference Series on Public Policy 42. 
Calomiris, Charles W., and Matthew Jaremski. 2016. "Deposit Insurance: Theories and Facts,” Annual Review of Financial Economics, forthcoming.

Calomiris, Charles W., Matthew Jaremski, Haelim Park, and Gary Richardson. 2015. "Liquidity Risk, Bank Networks, and the Value of Joining the Federal Reserve System”. Office of Financial Research Working Paper No. 15-05.

Calomiris, Charles W. and Charles M. Kahn. 1991. "The role of demandable debt in structuring optimal banking arrangements." American Economic Review: 497-513.

Calomiris, Charles W. and Joseph Mason. 1997. "Contagion and Bank Failures During the Great Depression.” American Economic Review 87, 863-883

Calomiris, Charles W. and Joseph Mason. 2003. "Fundamentals, Panics, and Bank Distress During the Great Depression.” American Economic Review 93, 1615-1647.

Calomiris, Charles W. and Andrew Powell. 2001. "Can emerging market bank regulators establish credible discipline? The case of Argentina, 1992-99." Prudential Supervision: what works and what doesn't. 147-196. Chicago: University of Chicago Press.

Calomiris, Charles W. and Larry Schweikart. 1991. "The panic of 1857: origins, transmission, and containment." Journal of Economic History 51.04: 807-834.

Calomiris, Charles W. and Eugene White. 1994. "The origins of federal deposit insurance." In The Regulated Economy: A Historical Approach to Political Economy. Chicago: University of Chicago Press.

Calomiris, Charles W. and Berry Wilson. 2004. "Bank Capital and Portfolio Management: The 1930s 'Capital Crunch’ and the Scramble to Shed Risk." Journal of Business 77: 421-456.

Caprio, Gerard, and Daniela Klingebiel. 1996. "Bank insolvencies: Cross-country experience.” World Bank Policy Research Paper 1620.

Carlson, Mark and David C. Wheelock. 2015. "Interbank Markets and Banking Crises: New Evidence on the Establishment and Impact of the Federal Reserve." Unpublished Working Paper.

Carter, Susan, Sigmund Carter, Scott, Haines, Michael, Olmstead, Alan, Sutch, Richard, and Wright, Gavin. 2006. Historical Statistics of the United States: Earliest Times to the Present, Millennial Edition. New York: Cambridge University Press, 4-39 to 4-88.

Chung, Ching-Yi and Gary Richardson. 2006. "Deposit Insurance Altered the Composition of Bank Suspensions during the 1920s: Evidence from the Archives of the Board of Governors." B.E. Journal of Economic Analysis \& Policy, vol. 0.

Cooke, Thornton. 1910. "The Insurance of Bank Deposits in the West: II". Quarterly Journal of Economics 24: 327-391.

Cull, Robert, Lemma W. Senbet, and Marco Sorge. 2005. "Deposit insurance and financial development." Journal of Money, Credit and Banking 37: 43-82.

Demirgüç-Kunt, Ask and Enrica Detragiache. 2002. "Does Deposit Insurance Increase Banking System Stability? An Empirical Investigation.” Journal of Monetary Economics 49: 1373-1406.

Demirgüç-Kunt, Asli, and Harry Huizinga. 2004. "Market discipline and deposit insurance." Journal of Monetary Economics 51.2: 375-399.

Demirgüç-Kunt, Asli, Edward J. Kane, and Luc Laeven. 2008. "Determinants of depositinsurance adoption and design." Journal of Financial Intermediation 17.3: 407-438.

Demirgüç-Kunt, Ask and Edward Kane. 2002. "Deposit Insurance Around the Globe: Where Does It Work?" NBER Working Paper. 
Economides, Nicholas, R. Glenn Hubbard, and Darius Palia. 1996. “The Political Economy of Branching Restrictions and Deposit Insurance: A Model of Monopolistic Competition among Small and Large Banks.” Journal of Law and Economics 39: 667-704.

Flood, Mark. 1998. U.S. Historical Data on Bank Market Structure, 1896-1955. Ann Arbor, MI: Inter-university Consortium for Political and Social Research.

Goldenweiser, E.A., et al. 1932. Bank Suspensions in the United States, 1892-1931. Material prepared for the information of the Federal Reserve System by the Federal Reserve Committee on Branch, Group, and Chain Banking. Federal Reserve Board of Governors.

Golembe, C. H., and C. Warburton. 1958."Insurance of Bank Obligations in Six States During the Period 1829-1866." Federal Deposit Insurance Corporation.

Gorton, Gary, and George Pennacchi. 1990. "Financial intermediaries and liquidity creation." Journal of Finance 45.1: 49-71.

Grossman, Richard. 1992. "Deposit Insurance, Regulation, and Moral Hazard in the Thrift Industry: Evidence from the 1930s.” American Economic Review 82: 800-21.

Haines, Michael R. 2004. Historical, Demographic, Economic, and Social Data: The United States, 1790-2000. ICPSR Study 2896. Ann Arbor, MI: Inter-university Consortium for Political and Social Research.

Honohan, Patrick, and Daniela Klingebiel. 2003. "The fiscal cost implications of an accommodating approach to banking crises." Journal of Banking and Finance 27.8: 1539-1560.

Hooks, Linda M. and Kenneth J. Robinson. 2002. "Deposit Insurance and Moral Hazard: Evidence from Texas Banking in the 1920s.” Journal of Economic History 62: 833-853.

James, John A. 1978. Money and Capital Markets in Postbellum America. Princeton: Princeton University Press.

James, John A., and David F. Weiman. 2010. "From drafts to checks: the evolution of correspondent banking networks and the formation of the modern US payments system, 1850-1914." Journal of Money, Credit and Banking 42: 237-265.

Jaremski, Matthew. 2013. National Bank Balance Sheets. Unpublished database collected from the Comptroller of the Currency's Annual Report.

Jaremski, Matthew. 2015. “Clearinghouses as Credit Regulators Before the Fed?” Journal of Financial Stability 17, 10-21.

Jaremski, Matthew, and Peter L. Rousseau. 2015. “The Dawn of an 'Age of Deposits' in the United States”. NBER Working Paper W21503.

Kemmerer, Edwin. 1910. Seasonal Variations in the Relative Demand for Money and Capital in the United States. National Monetary Commission, U.S. Government Printing Office: Washington DC.

Laeven, Luc, and Fabian Valencia. 2013. "Systemic banking crises database." IMF Economic Review 61.2: 225-270.

Martinez-Peria, Maria Soledad, and Sergio L. Schmukler. 2001. "Do depositors punish banks for bad behavior? Market discipline, deposit insurance, and banking crises." Journal of Finance 56.3: 1029-1051.

Merton, Robert C. 1977. "An analytic derivation of the cost of deposit insurance and loan guarantees an application of modern option pricing theory." Journal of Banking \& Finance 1.1: 3-11.

Minnesota Population Center. 2004. National Historical Geographic Information System: Prerelease Version 0.1. Minneapolis, MN: University of Minnesota. http://www.nhgis.org. 
Mitchener, Kris and Matthew Jaremski. 2015. “The Evolution of Bank Supervisory Institutions: Evidence from American States”. Journal of Economic History 75:819-859.

Mitchener, Kris James, and Gary Richardson. 2015. "The Reserve Pyramid and Interbank Contagion during the Great Depression." Current Federal Reserve Policy Under the Lens of Economic History: 217-240.

Office of the Comptroller of the Currency. Various Years. Annual Report of the Comptroller of the Currency. Washington: Government Printing Office.

Prins, Nomi. 2009. It Take a Pillage: Behind the Bailouts, Bonuses, and Backroom Deals from Washington to Wall Street. Hoboken, New Jersey: John Wiley and Sons.

Rajan, Raghuram, and R. Ramcharan. 2015. "The Anatomy of a Credit Crisis: The Boom and Bust in Farm Land Prices in the United States in the 1920s." American Economic Review 105: 1439-77.

Robb, Thomas B. 1921. The Guaranty of Bank Deposits. Boston: Houghton Mifflin Co.

Sprague, O.M.W. 1910. History of Crises under the National Banking System. Washington, DC: National Monetary Commission, Senate Document 538, 61st Congress, 2d Session.

Warburton, Clark 1959. Deposit Insurance in Eight States During the Period 1908-1930. Federal Deposit Insurance Corporation.

Wheelock, David. 1992. "Deposit Insurance and Bank Failures: New Evidence from the 1920s.” Economic Inquiry 33: 530-543.

Wheelock, David C. 1993. "Government policy and banking market structure in the 1920s." Journal of Economic History 53: 857-879.

Wheelock, David C., and Subal C. Kumbhakar. 1994. “'The Slack Banker Dances': Deposit Insurance and Risk-Taking in the Banking Collapse of the 1920s." Explorations in Economic History 31: 357-375.

Wheelock, David and Subal Kumbhakar. 1995. "Which banks choose deposit insurance? Evidence of adverse selection and moral hazard in a voluntary insurance system." Journal of Money, Credit and Banking: 186-201.

Wheelock, David and Paul Wilson. 1995. “Explaining Bank Failures: Deposit Insurance, Regulation, and Efficiency.” Review of Economic and Statistics 77: 689-700.

White, Eugene. 1981. "State-Sponsored Insurance of Bank Deposits in the United States, 19071929.” Journal of Economic History 41: 537-557.

White, Eugene. 1983. The Regulation and Reform of the American Banking System, 1900-1929. Princeton: Princeton University Press.

Wicker, Elmus. 2000. Banking Panics of the Gilded Age. Cambridge, UK: Cambridge University Press.

Yan, Xing, et al. 2014. "Market discipline and deposit guarantee: Evidence from Australian banks." International Review of Finance 14.3: 431-457. 


\section{Figure 1: Map of Deposit Insurance States and Comparison States}

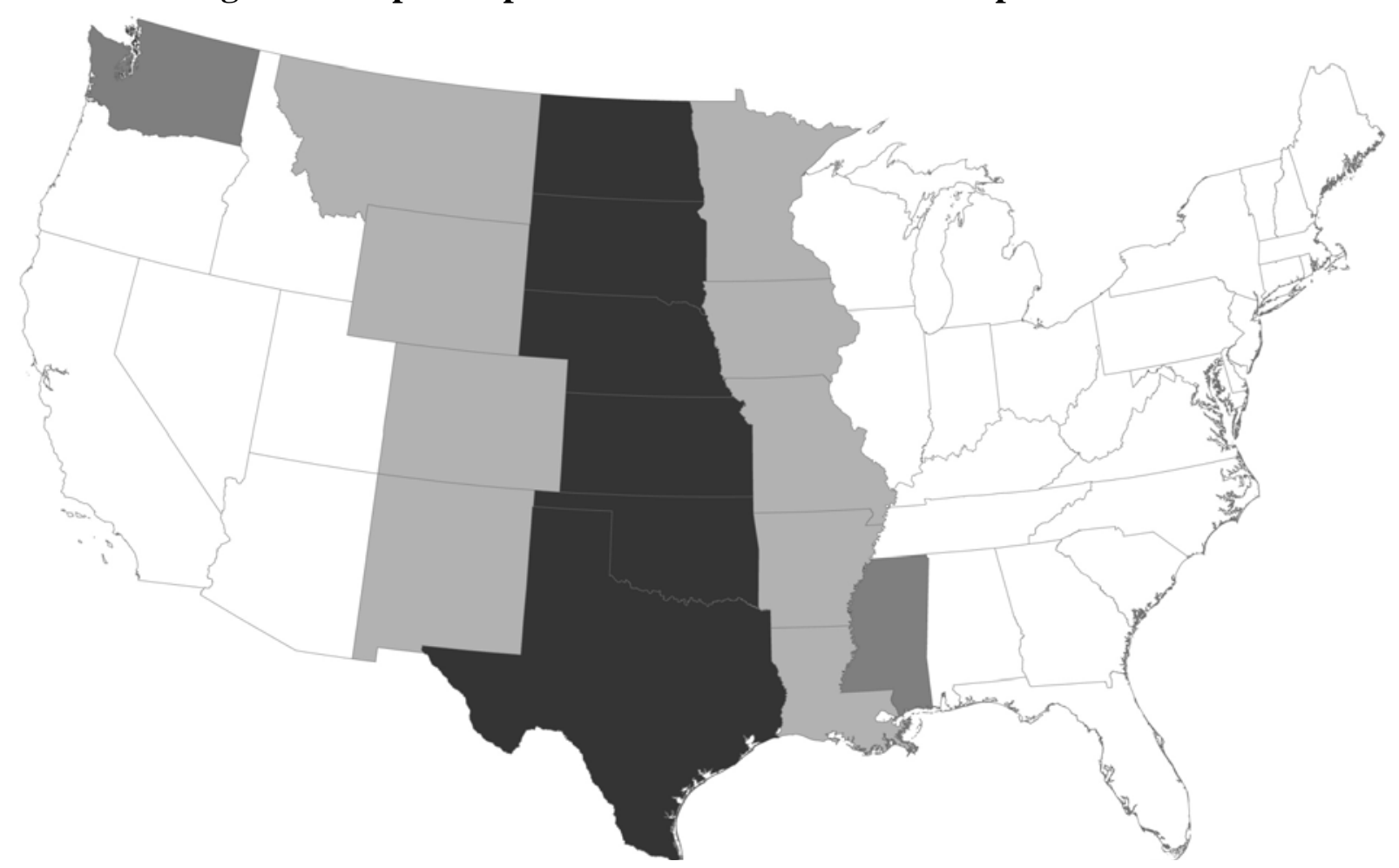

Notes: The figure maps out deposit insurance states included in the analysis in black, deposit insurance states not included in the analysis in dark grey, and bordering non-deposit insurance states included in the analysis as a comparison group in light gray. Boundaries obtained from Minnesota Population Center (2004). 
Figure 2: Total Value of Deposits (1900-1925)

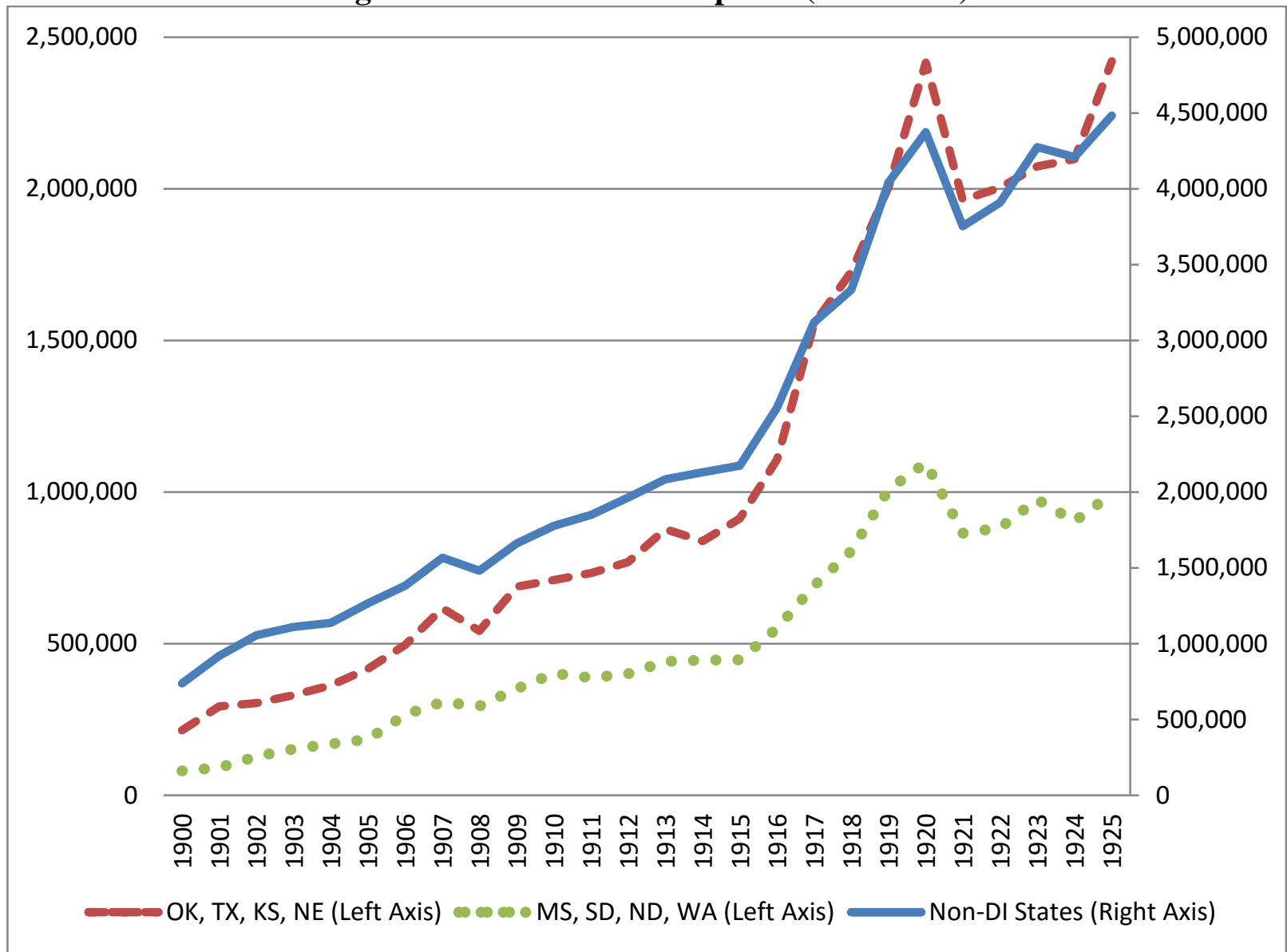

Notes: Figures display the aggregate deposits by state group. "Non-DI States" consists only of the comparison group of non-deposit insurance states seen in Figure 1. See Data section for sources. 
Figure 3: Index of Production and Prices for 12 Important Crops (1904-1925)

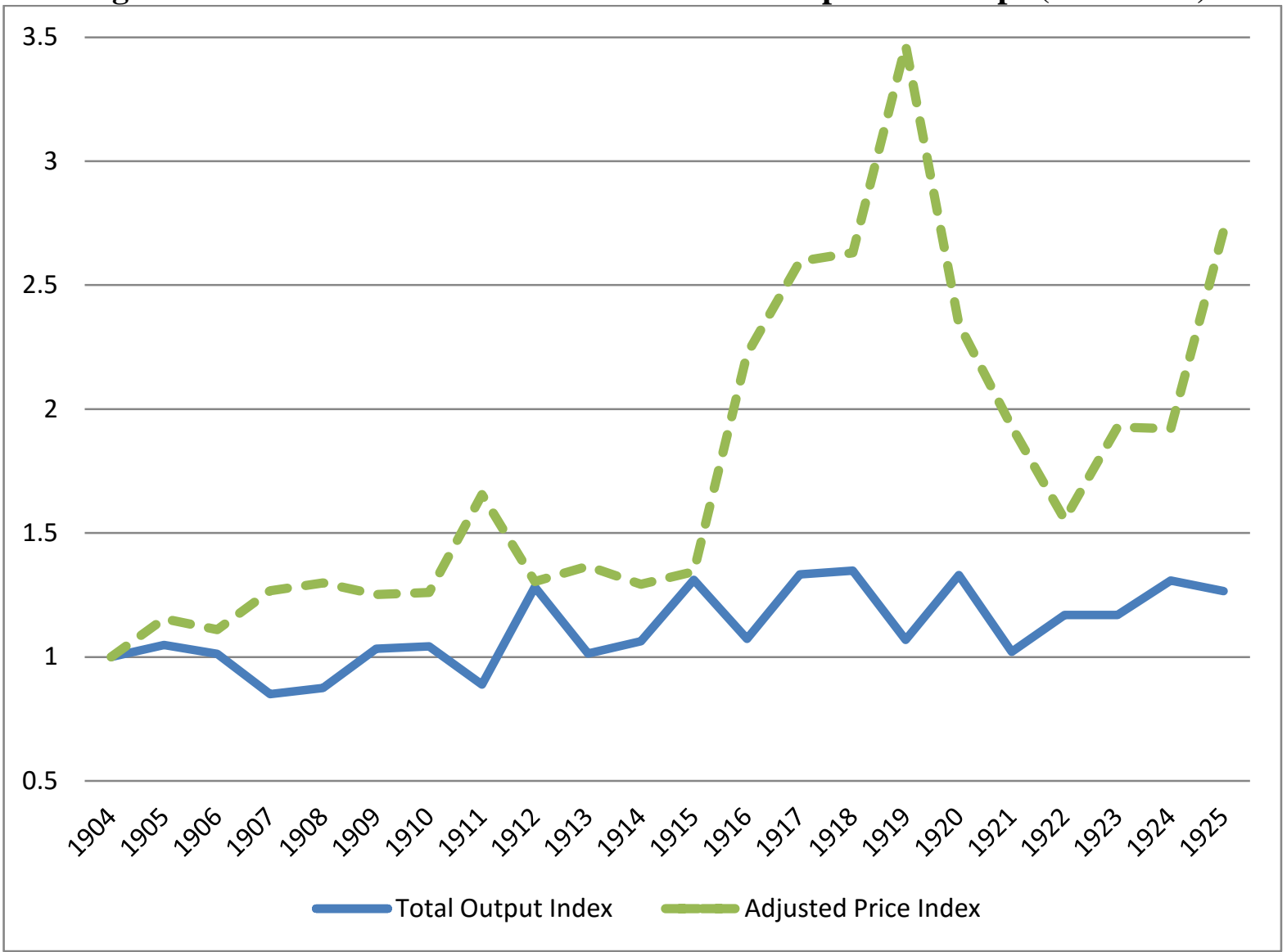

Notes: Table presents output and price indices for 12 crops: corn, barley, flaxseed, rice, oats, wheat, hay, rye, buckwheat, cotton, tobacco, sweet potatoes, and Irish potatoes. Output is based off the physical quantity produced and price is adjusted for unit values. All values are normalized to 1 in 1904. 
Figure 4: Ratio of State to National Bank Deposits Across State Groups (1900-1925)

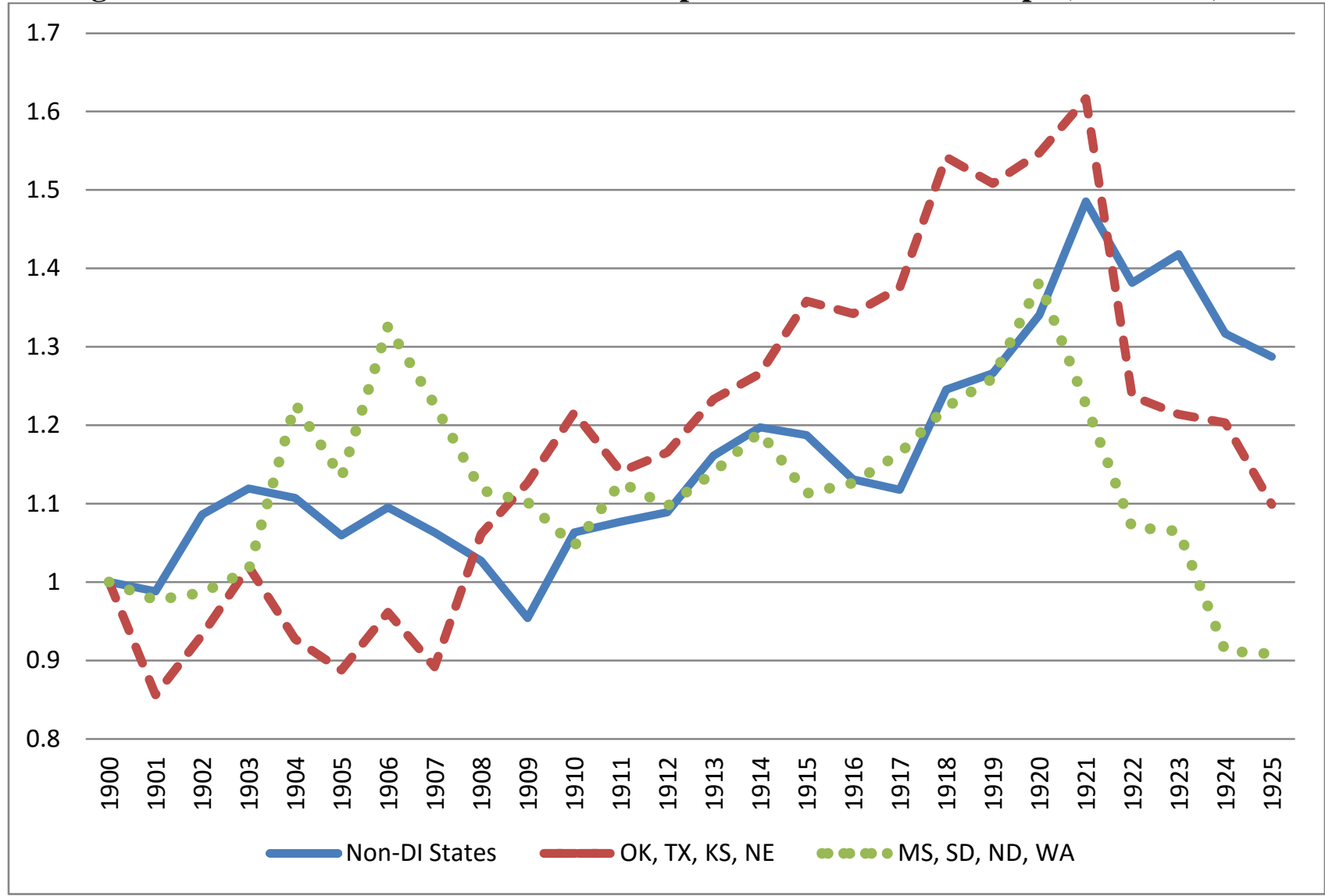

Notes: Figures display the ratio of state bank aggregates to national bank aggregates by state group. The ratios are normalized to 1 in 1900. "Non-DI States" consists only of the comparison group of non-deposit insurance states seen in Figure 1. See Data section for sources. 
Figure 5: Ratio of State to National Bank Deposits in States That Passed Inactive Laws

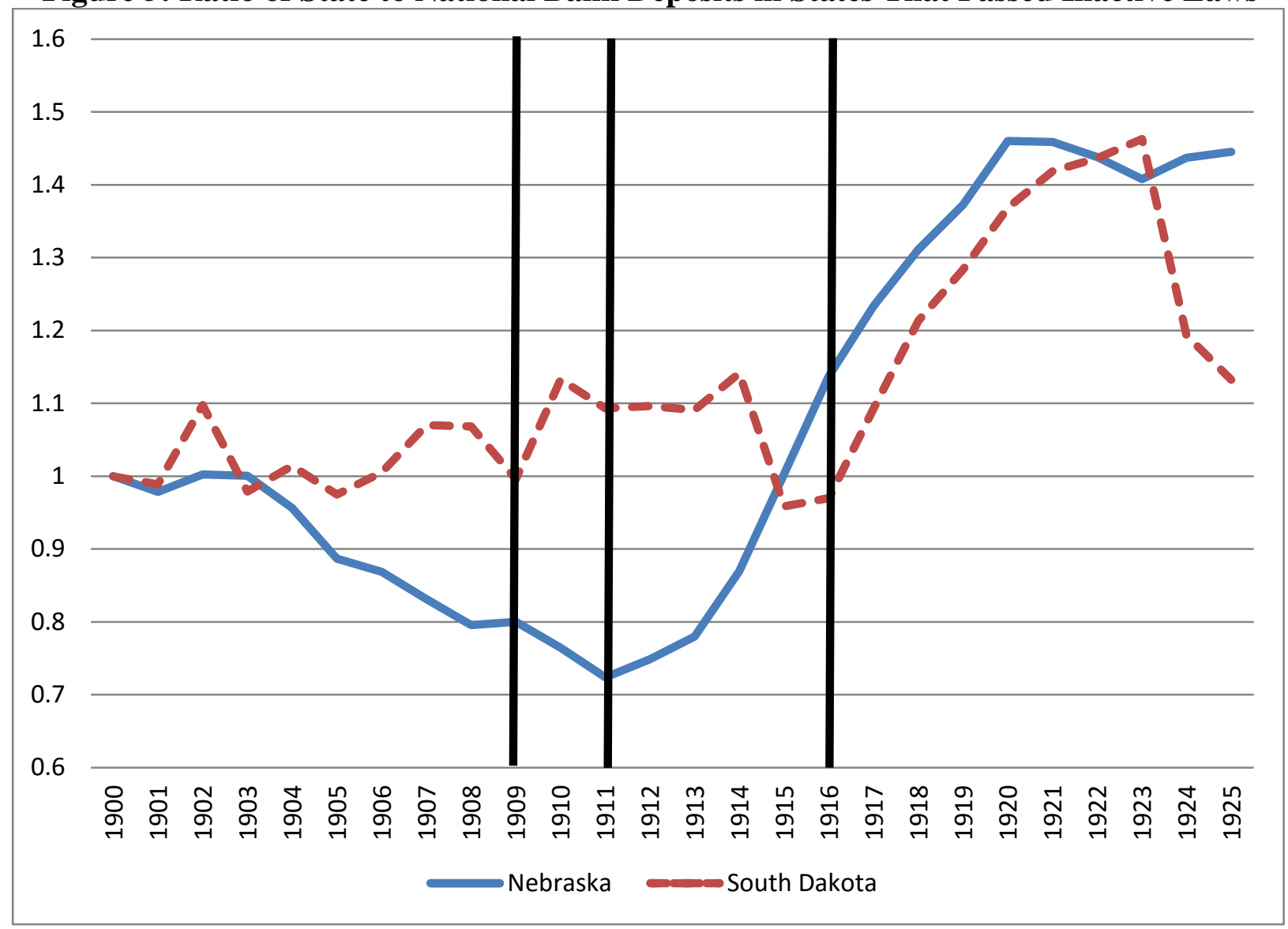

Notes: Figures present the ratios of state bank deposits to national bank deposits in each state. The ratios are normalized to 1 in 1900. The first vertical line denotes each state's passage of an inactive deposit insurance law in both states, the second line denotes the year deposit insurance was made active by additional legislation in Nebraska and the third line denotes the year deposit insurance was made active by additional legislation in South Dakota. See Data section for sources. 
Figure 6: Effect of Deposit Insurance At State-Level (1908-1920)

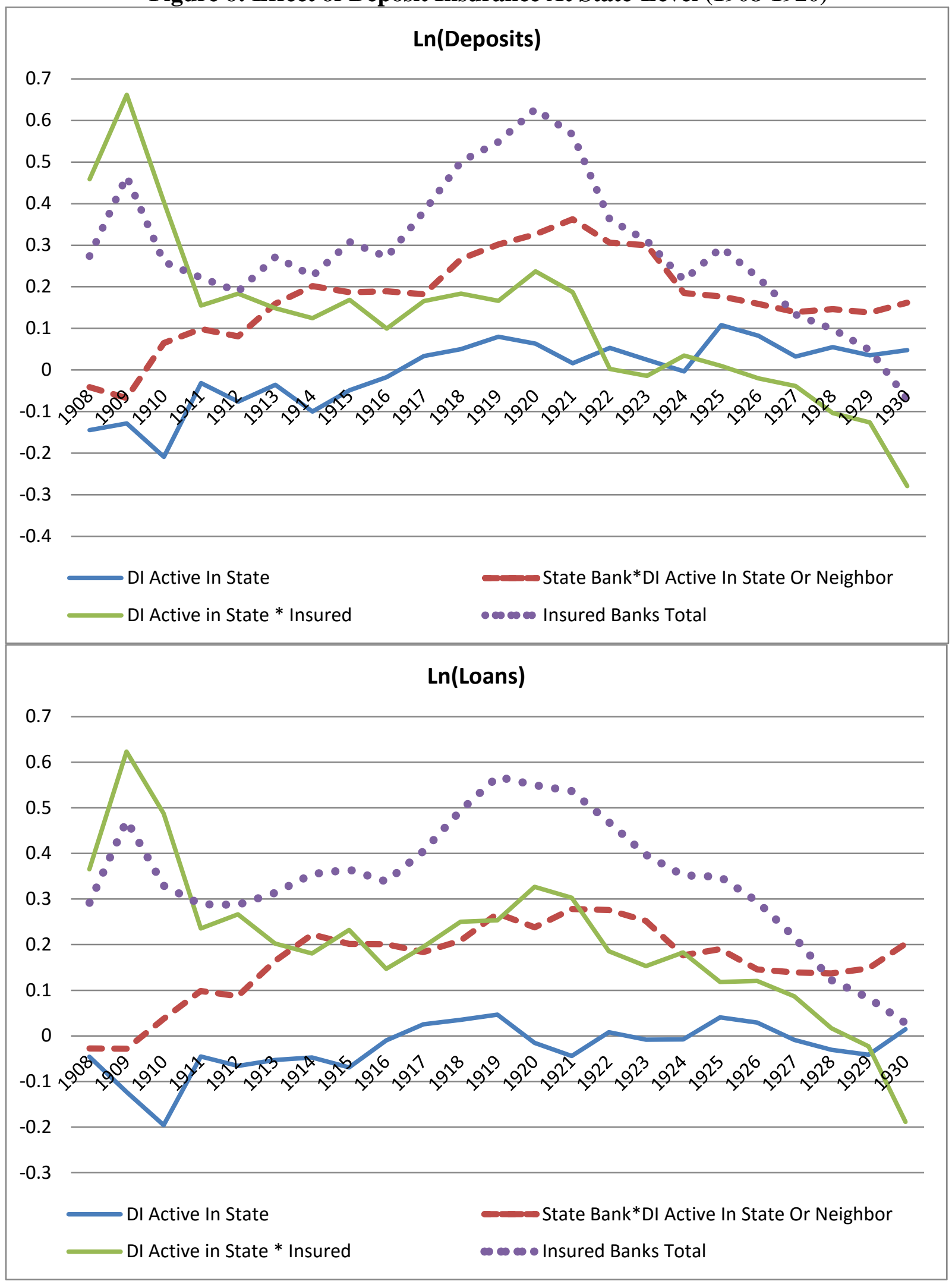

Notes: Figures display the coefficients from the estimation of Equation (3) in the text. 
Table 1: Characteristics of Deposit Insurance States Relative to Other States

\begin{tabular}{|c|c|c|c|c|c|c|c|c|c|c|}
\hline & $\begin{array}{c}\text { Branching } \\
\text { Allowed }\end{array}$ & $\begin{array}{c}\text { Fraction } \\
\text { Urban }\end{array}$ & $\begin{array}{c}\text { Crop } \\
\text { Output } \\
\text { Per } \\
\text { Person }\end{array}$ & $\begin{array}{c}\text { Bank } \\
\text { Failure } \\
\text { Rate } \\
\text { 1903-08 }\end{array}$ & $\begin{array}{c}\text { \# of } \\
\text { State } \\
\text { Banks }\end{array}$ & $\begin{array}{c}\text { \# of } \\
\text { National } \\
\text { Banks }\end{array}$ & $\begin{array}{l}\text { Avg Assets } \\
\text { of State } \\
\text { Banks }\end{array}$ & $\begin{array}{c}\text { Avg Assets } \\
\text { of National } \\
\text { Banks }\end{array}$ & $\begin{array}{c}\text { Paid In } \\
\text { Capital } \\
\text { Gini } \\
\text { Coeff. }\end{array}$ & $\begin{array}{c}\text { Acres in } \\
\text { Largest } \\
\text { Crop }\end{array}$ \\
\hline KS & 0 & $27.9 \%$ & 99.4 & $1.7 \%$ & 750 & 209 & 127,095 & 502,958 & $44.8 \%$ & $53.0 \%$ \\
\hline MS & 0 & $10.9 \%$ & 62.8 & $4.6 \%$ & 289 & 30 & 197,348 & 669,863 & $48.9 \%$ & $37.5 \%$ \\
\hline ND & 0 & $10.6 \%$ & 235.8 & $1.9 \%$ & 422 & 132 & 69,448 & 244,971 & $35.9 \%$ & $63.5 \%$ \\
\hline $\mathrm{NE}$ & 0 & $25.8 \%$ & 125.0 & $0.8 \%$ & 629 & 210 & 123,152 & 612,671 & $49.8 \%$ & $57.5 \%$ \\
\hline OK & 0 & $18.6 \%$ & 65.7 & $3.1 \%$ & 496 & 309 & 59,892 & 222,361 & $43.7 \%$ & $61.0 \%$ \\
\hline SD & 0 & $12.9 \%$ & 164.6 & $3.3 \%$ & 413 & 90 & 102,520 & 341,215 & $46.0 \%$ & $38.0 \%$ \\
\hline $\mathrm{TX}$ & 0 & $22.9 \%$ & 60.8 & $2.1 \%$ & 507 & 534 & 110,570 & 426,832 & $54.5 \%$ & $31.5 \%$ \\
\hline WA & 0 & $51.8 \%$ & 54.9 & $10.0 \%$ & 230 & 63 & 386,385 & $1,468,324$ & $60.9 \%$ & $79.5 \%$ \\
\hline DI States & " 0 & $222.7 \%$ & "109 & $3.4 \%$ & "467 & 197 & $=147,051$ & $\begin{array}{l}561,149 \\
\end{array}$ & 48.1\% & "52.7\% \\
\hline AR & 0 & $12.1 \%$ & 57.7 & $8.5 \%$ & 325 & 41 & 152,233 & 538,476 & $56.0 \%$ & $47.0 \%$ \\
\hline $\mathrm{CO}$ & 0 & $50.0 \%$ & 50.1 & $2.0 \%$ & 135 & 115 & 222,792 & $1,057,124$ & $54.5 \%$ & $27.0 \%$ \\
\hline IA & 0 & $29.6 \%$ & 109.6 & $1.0 \%$ & 1231 & 317 & 240,943 & 542,900 & $44.1 \%$ & $60.5 \%$ \\
\hline NM & 0 & $14.6 \%$ & 24.7 & $0.0 \%$ & 27 & 42 & 151,347 & 386,391 & $37.9 \%$ & $46.5 \%$ \\
\hline MN & 0 & $39.8 \%$ & 72.2 & $0.6 \%$ & 640 & 263 & 186,406 & 761,341 & $58.0 \%$ & $30.5 \%$ \\
\hline MO & 0 & $41.2 \%$ & 51.9 & $1.2 \%$ & 1031 & 122 & 329,713 & $2,766,051$ & $75.6 \%$ & $68.0 \%$ \\
\hline MT & 0 & $35.4 \%$ & 65.6 & $2.7 \%$ & 91 & 41 & 410,690 & 980,026 & $45.8 \%$ & $47.5 \%$ \\
\hline LA & 1 & $29.4 \%$ & 38.2 & $0.8 \%$ & 183 & 37 & 508,298 & $1,662,140$ & $72.6 \%$ & $52.5 \%$ \\
\hline \multicolumn{11}{|l|}{$\begin{array}{l}\text { Non-DI } \\
\text { Comparison }\end{array}$} \\
\hline States & $12.5 \%$ & $31.5 \%$ & 59 & $2.1 \%$ & 458 & 122 & 275,303 & $1,086,806$ & $55.6 \%$ & $47.4 \%$ \\
\hline $\mathrm{AL}$ & 0 & $16.4 \%$ & 51.4 & $3.9 \%$ & 201 & 77 & 246,546 & 626,804 & $54.3 \%$ & $37.5 \%$ \\
\hline $\mathrm{AZ}$ & 1 & $29.1 \%$ & 24.7 & $11.4 \%$ & 30 & 14 & 354,242 & 616,693 & $38.5 \%$ & $40.0 \%$ \\
\hline CA & 1 & $60.8 \%$ & 53.5 & $2.3 \%$ & 480 & 140 & $1,165,170$ & $1,831,569$ & $68.2 \%$ & $53.0 \%$ \\
\hline CT & 0 & $64.7 \%$ & 17.6 & $0.5 \%$ & 135 & 81 & $2,326,150$ & $1,398,864$ & $47.7 \%$ & $46.0 \%$ \\
\hline $\mathrm{DE}$ & 1 & $47.7 \%$ & 36.1 & $0.0 \%$ & 13 & 28 & $1,939,751$ & 599,001 & $54.2 \%$ & $58.0 \%$ \\
\hline FL & 0 & $28.1 \%$ & 36.1 & $5.8 \%$ & 104 & 40 & 184,477 & 843,514 & $56.1 \%$ & $56.0 \%$ \\
\hline GA & 1 & $20.0 \%$ & 63.0 & $3.0 \%$ & 500 & 97 & 177,710 & 681,595 & $55.6 \%$ & $36.5 \%$ \\
\hline ID & 0 & $18.9 \%$ & 84.0 & $2.8 \%$ & 115 & 39 & 175,940 & 445,080 & $49.7 \%$ & $44.5 \%$ \\
\hline IL & 0 & $60.4 \%$ & 51.8 & $0.7 \%$ & 1122 & 410 & 637,255 & $1,626,815$ & $68.8 \%$ & $60.0 \%$ \\
\hline IN & 0 & $40.8 \%$ & 59.0 & $1.0 \%$ & 552 & 243 & 284,693 & 812,720 & $52.0 \%$ & $55.0 \%$ \\
\hline KY & 1 & $23.8 \%$ & 47.2 & $1.3 \%$ & 453 & 146 & 215,767 & 715,304 & $60.0 \%$ & $70.5 \%$ \\
\hline MA & 1 & $88.5 \%$ & 8.9 & $1.5 \%$ & 298 & 199 & $3,359,166$ & $2,619,930$ & $53.2 \%$ & $48.5 \%$ \\
\hline MD & 1 & $50.6 \%$ & 27.3 & $4.6 \%$ & 107 & 102 & $1,539,595$ & $1,424,763$ & $71.2 \%$ & $46.0 \%$ \\
\hline $\mathrm{ME}$ & 1 & $35.0 \%$ & 41.0 & $1.3 \%$ & 92 & 78 & $1,433,605$ & 712,871 & $41.9 \%$ & $44.5 \%$ \\
\hline MI & 1 & $45.8 \%$ & 45.0 & $1.5 \%$ & 616 & 97 & 437,624 & $1,460,980$ & $57.8 \%$ & $29.5 \%$ \\
\hline NC & 1 & $13.7 \%$ & 49.2 & $4.7 \%$ & 296 & 69 & 149,974 & 617,310 & $60.5 \%$ & $47.0 \%$ \\
\hline NH & 0 & $50.8 \%$ & 30.7 & $2.5 \%$ & 65 & 58 & $1,467,579$ & 586,282 & $33.2 \%$ & $37.0 \%$ \\
\hline $\mathrm{NJ}$ & 1 & $75.5 \%$ & 14.0 & $2.2 \%$ & 131 & 174 & $2,288,778$ & $1,214,383$ & $53.4 \%$ & $44.5 \%$ \\
\hline NV & 0 & $17.0 \%$ & 63.7 & $33.3 \%$ & 32 & 10 & 497,646 & $1,034,779$ & $61.2 \%$ & $36.0 \%$ \\
\hline NY & 1 & $77.9 \%$ & 19.5 & $3.3 \%$ & 592 & 424 & $5,956,509$ & $5,014,294$ & $76.6 \%$ & $41.5 \%$ \\
\hline $\mathrm{OH}$ & 0 & $54.5 \%$ & 39.4 & $3.7 \%$ & 715 & 366 & 647,493 & $1,311,713$ & $66.8 \%$ & $49.0 \%$ \\
\hline OR & 0 & $43.9 \%$ & 59.3 & $7.2 \%$ & 139 & 64 & 409,494 & 824,112 & $55.0 \%$ & $58.5 \%$ \\
\hline PA & 0 & $59.4 \%$ & 18.6 & $3.0 \%$ & 555 & 766 & $1,750,218$ & $1,501,572$ & $61.5 \%$ & $30.0 \%$ \\
\hline RI & 1 & $90.6 \%$ & 7.5 & $2.8 \%$ & 34 & 23 & $5,603,607$ & $1,881,683$ & $56.4 \%$ & $57.5 \%$ \\
\hline SC & 1 & $15.0 \%$ & 66.2 & $2.9 \%$ & 234 & 30 & 208,992 & 878,518 & $47.3 \%$ & $32.0 \%$ \\
\hline $\mathrm{TN}$ & 1 & $19.4 \%$ & 43.1 & $7.2 \%$ & 326 & 87 & 228,776 & 876,978 & $63.4 \%$ & $61.0 \%$ \\
\hline UT & 0 & $45.0 \%$ & 40.2 & $0.0 \%$ & 57 & 21 & 621,715 & $1,093,651$ & $54.1 \%$ & $52.5 \%$ \\
\hline VA & 0 & $22.2 \%$ & 38.4 & $0.9 \%$ & 254 & 106 & 266,436 & $1,010,315$ & $61.5 \%$ & $55.5 \%$ \\
\hline VT & 0 & $26.7 \%$ & 60.2 & $2.2 \%$ & 50 & 52 & $1,363,960$ & 595,354 & $35.8 \%$ & $43.5 \%$ \\
\hline WI & 0 & $42.3 \%$ & 50.5 & $1.5 \%$ & 458 & 131 & 291,191 & $1,183,424$ & $61.3 \%$ & $40.0 \%$ \\
\hline WV & 0 & $17.8 \%$ & 27.9 & $2.0 \%$ & 174 & 96 & 395,354 & 611,169 & $50.4 \%$ & $61.0 \%$ \\
\hline WY & 0 & $29.5 \%$ & 59.7 & $2.7 \%$ & 47 & 31 & 116,784 & 515,068 & $43.0 \%$ & $63.0 \%$ \\
\hline Non-DI States & "46.9\% & "41.6\% & 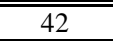 & 3.9\% & 281 & 134 & $1,148,194$ & $101,161,472$ & "55.3\% & "48.0\% \\
\hline
\end{tabular}

Notes: See Data section for sources. 
Table 2: Data Availability at Bank-Level

\begin{tabular}{|c|c|c|c|}
\hline States & Years When Balance Sheet Data Are Available & $\begin{array}{l}\text { Missing } \\
\text { Reports }\end{array}$ & $\begin{array}{l}\text { Included } \\
\text { in Sample }\end{array}$ \\
\hline Arkansas & $1914,1916,1918,1921$ & \multirow{4}{*}{$1919-1920$} & No \\
\hline New Mexico & 1917-1918, 1921 & & No \\
\hline Wyoming & None Available & & No \\
\hline Colorado & 1908-1921 & & No \\
\hline North Dakota & 1900-1910, 1912 & \multirow[t]{2}{*}{1911} & No \\
\hline Oklahoma & 1908, 1910, 1912 ,1914, 1916, 1918, 1920 & & No \\
\hline Texas & $1905-1912,1914$ & \multirow[t]{2}{*}{1913} & No \\
\hline Iowa & $\begin{array}{c}\text { 1901, 1903, 1905, 1906, 1908, 1910, 1912, 1914, 1916, } \\
\text { 1918, } 1921\end{array}$ & & Yes \\
\hline Kansas & 1900, 1902 ,1904, 1906,1908 ,1910, 1914, 1918 & \multirow{7}{*}{ 1903, 1912} & Yes \\
\hline Louisiana & 1900-1902, 1904-1911, 1913-1915, 1917, 1919, 1921 & & Yes \\
\hline Minnesota & $1900-1914,1916-1920$ & & Yes \\
\hline Missouri & $\begin{array}{c}\text { 1900, 1902, 1904, 1906, 1908, 1910, 1912, 1914, 1916, } \\
1918,1920\end{array}$ & & Yes \\
\hline Montana & 1900-1906, 1908, 1910, 1912, 1914-1920 & & Yes \\
\hline Nebraska & $1893-1916,1918,1920$ & & Yes \\
\hline South Dakota & $\begin{array}{c}\text { 1902, 1904, 1906, 1908, 1910, } 1912,1914,1916,1918, \\
1920\end{array}$ & & Yes \\
\hline
\end{tabular}

Notes: Table displays information on the state banking reports published by states that passed deposit insurance before 1914 and surrounding comparison states. "Missing Reports" denotes years when balance sheet was reported but the reports have not been found. "Included in Sample" denotes states that will be included in the bank-level regressions. 
Table 3: Examining the Trends in Aggregate Deposits and Loans Before Deposit Insurance (1900-1908)

\begin{tabular}{|c|c|c|c|c|}
\hline & \multicolumn{2}{|c|}{ In(Individual Deposits) } & \multicolumn{2}{|c|}{$\ln ($ Loans $)$} \\
\hline & (1) & $(2)$ & (3) & (4) \\
\hline \multirow[t]{2}{*}{ DI Ever Installed * Linear Trend } & 0.009 & 0.014 & 0.003 & 0.005 \\
\hline & {$[0.016]$} & [0.018] & [0.021] & [0.022] \\
\hline \multirow[t]{2}{*}{ DI Ever Installed * State Bank * Linear Trend } & & -0.009 & & -0.005 \\
\hline & & [0.014] & & {$[0.010]$} \\
\hline Location*Charter Type Fixed Effects? & $\begin{array}{l}\text { State-Bank } \\
\text { Type }\end{array}$ & $\begin{array}{l}\text { State-Bank } \\
\text { Type }\end{array}$ & $\begin{array}{l}\text { State-Bank } \\
\text { Type }\end{array}$ & $\begin{array}{c}\text { State-Bank } \\
\text { Type }\end{array}$ \\
\hline Year Fixed Effects? & Yes & Yes & Yes & Yes \\
\hline Census Variables? & Yes & Yes & Yes & Yes \\
\hline Observations & 270 & 270 & 270 & 270 \\
\hline R-squared & 0.838 & 0.838 & 0.851 & 0.851 \\
\hline \multicolumn{5}{|c|}{$\begin{array}{l}\text { Notes: Table displays the results of a linear regression with the dependent variable specified by the column titles. Each } \\
\text { observation is either the state bank or national bank aggregate for a particular state in a particular year. Only those states } \\
\text { that passed deposit insurance before } 1914 \text { and surrounding comparison states are included. Census variables include the } \\
\text { logarithm of population, the logarithms of crop and manufacturing output per person, the percent change in crop output per } \\
\text { period, and the fraction of population living in a location of } 2,500 \text { or more. Standard errors clustered at the state-level are } \\
\text { provided in brackets. * denotes significance at } 10 \% ; * * \text { at } 5 \% \text { level and } * * * \text { at } 1 \% \text { level. }\end{array}$} \\
\hline
\end{tabular}


Table 4: Linear Determinants of Aggregate Banks, Deposits, and Loans at the State-Level (1900-1920)

\begin{tabular}{|c|c|c|c|c|c|c|}
\hline & \multicolumn{2}{|c|}{ Ln(\# of Banks) } & \multicolumn{2}{|c|}{ Ln(Individual Deposits) } & \multicolumn{2}{|c|}{ Ln(Loans) } \\
\hline & (1) & (2) & (3) & (4) & (5) & (6) \\
\hline \multirow[t]{2}{*}{ DI Active In State } & -0.031 & -0.114 & 0.092 & -0.054 & $0.124 * *$ & -0.054 \\
\hline & [0.063] & {$[0.070]$} & [0.053] & {$[0.066]$} & {$[0.055]$} & [0.061] \\
\hline State Bank * DI Active & & 0.137 & & 0.102 & & $0.092 *$ \\
\hline in State or Neighbor & & [0.091] & & [0.064] & & [0.048] \\
\hline DI Active in State & & 0.113 & & $0.252 * *$ & & $0.320 * * *$ \\
\hline * State Bank & & [0.169] & & {$[0.089]$} & & [0.087] \\
\hline Location*Charter Type Fixed & State-Bank & State-Bank & State-Bank & State-Bank & State-Bank & State-Bank \\
\hline Effects? & Type & Type & Type & Type & Type & Type \\
\hline Year Fixed Effects? & Yes & Yes & Yes & Yes & Yes & Yes \\
\hline Census Variables? & Yes & Yes & Yes & Yes & Yes & Yes \\
\hline Observations & 630 & 630 & 630 & 630 & 630 & 630 \\
\hline R-squared & 0.850 & 0.861 & 0.868 & 0.884 & 0.885 & 0.904 \\
\hline $\begin{array}{l}\text { Notes: Table displays the resul } \\
\text { observation is either the state b } \\
\text { passed deposit insurance befor } \\
\text { population, the logarithms of c } \\
\text { fraction of population living in } \\
\text { denotes significance at } 10 \% \text {; }\end{array}$ & $\begin{array}{l}\text { of a linear re } \\
\mathrm{k} \text { or national } \\
914 \text { and surr } \\
\text { and manufa } \\
\text { location of } 2\end{array}$ & $\begin{array}{l}\text { ession with } t \\
\text { ank aggregat } \\
\text { anding comp } \\
\text { turing output } \\
00 \text { or more. }\end{array}$ & $\begin{array}{l}\text { pendent varia } \\
\text { a particular st } \\
\text { I states are in } \\
\text { erson, the per } \\
\text { ard errors clus }\end{array}$ & $\begin{array}{l}\text { specified bj } \\
\text { in a particu } \\
\text { ded. Census } \\
\text { nt change in } \\
\text { ed at the sta }\end{array}$ & $\begin{array}{l}\text { olumn titles. } \\
\text { r. Only those } \\
\text { les include th } \\
\text { utput per per } \\
\text { are provide }\end{array}$ & $\begin{array}{l}\text { ch } \\
\text { tes that } \\
\text { ogarithm of } \\
\text {, and the } \\
\text { brackets. * }\end{array}$ \\
\hline
\end{tabular}


Table 5: Effect of Deposit Insurance on Deposits and Loans at the Bank-Level (1900-1920)

\begin{tabular}{|c|c|c|c|c|c|c|c|c|}
\hline \multirow[b]{3}{*}{ DI Active In State } & \multicolumn{4}{|c|}{ Ln(Individual Deposits) } & \multicolumn{4}{|c|}{ Ln(Loans) } \\
\hline & (1) & $(2)$ & (3) & (4) & (5) & (6) & (7) & (8) \\
\hline & $\begin{array}{c}-0.138 * * * \\
{[0.019]}\end{array}$ & $\begin{array}{c}-0.139 * * * \\
{[0.019]}\end{array}$ & $\begin{array}{c}-0.255^{* * *} \\
{[0.022]}\end{array}$ & $\begin{array}{c}-0.102 \\
{[0.074]}\end{array}$ & $\begin{array}{c}-0.065^{* * *} \\
{[0.018]}\end{array}$ & $\begin{array}{c}-0.066 * * * \\
{[0.018]}\end{array}$ & $\begin{array}{c}-0.195 * * * \\
{[0.021]}\end{array}$ & $\begin{array}{c}-0.094 * \\
{[0.056]}\end{array}$ \\
\hline State Bank * DI Active & -0.014 & -0.013 & -0.014 & -0.013 & $0.068 * * *$ & $0.070 * * *$ & $0.068 * * *$ & $0.069 * * *$ \\
\hline in State or Neighbor & [0.012] & [0.012] & [0.012] & [0.012] & {$[0.011]$} & {$[0.011]$} & {$[0.011]$} & {$[0.011]$} \\
\hline DI Active in State*Member & $0.308 * * *$ & $0.209 * * *$ & $0.260 * * *$ & 0.109 & $0.249 * * *$ & $0.128 * * *$ & $0.198 * * *$ & 0.120 \\
\hline Bank & {$[0.021]$} & {$[0.025]$} & {$[0.024]$} & {$[0.087]$} & {$[0.021]$} & {$[0.025]$} & {$[0.025]$} & {$[0.083]$} \\
\hline DI Active in State*Member & & $0.173 * * *$ & & & & $0.212 * * *$ & & \\
\hline Bank *Small Bank & & {$[0.026]$} & & & & {$[0.027]$} & & \\
\hline DI Active in State*Young & & & $0.295 * * *$ & & & & $0.329 * * *$ & \\
\hline Bank & & & {$[0.028]$} & & & & [0.030] & \\
\hline DI Active in State*Member & & & $0.061^{*}$ & & & & $0.063^{*}$ & \\
\hline Bank *Young Bank & & & [0.035] & & & & [0.038] & \\
\hline DI Active in State*Crop & & & & -0.010 & & & & 0.008 \\
\hline Value & & & & [0.018] & & & & {$[0.014]$} \\
\hline DI Active in State*Member & & & & $0.054 * *$ & & & & $0.035 *$ \\
\hline Bank*Crop Value & & & & [0.021] & & & & {$[0.021]$} \\
\hline Bank Fixed Effects? & Yes & Yes & Yes & Yes & Yes & Yes & Yes & Yes \\
\hline Year Fixed Effects? & Yes & Yes & Yes & Yes & Yes & Yes & Yes & Yes \\
\hline Census Variables? & Yes & Yes & Yes & Yes & Yes & Yes & Yes & Yes \\
\hline Observations & 65,730 & 65,730 & 65,730 & 65,730 & 65,730 & 65,730 & 65,730 & 65,730 \\
\hline R-squared & 0.317 & 0.319 & 0.327 & 0.317 & 0.323 & 0.325 & 0.334 & 0.323 \\
\hline $\begin{array}{l}\text { Notes: Table displays the res } \\
\text { year. Only states that publish } \\
\text { logarithm of population, the } \\
\text { fraction of population living } \\
\text { operated in the county. Smal } \\
\text { errors clustered at the county }\end{array}$ & $\begin{array}{l}\text { a linear reg } \\
\text { a between } 1 \\
\text { hms of crop } \\
\text { cation of } 2,5 \\
\text { denotes ba } \\
\text { are provide }\end{array}$ & $\begin{array}{l}\text { ssion with th } \\
00 \text { and } 1920 \\
\text { nd manufact } \\
0 \text { or more, } n \\
\mathrm{k} \text { in the bott } \\
\text { in brackets. }\end{array}$ & $\begin{array}{l}\text { e dependen } \\
\text { are included } \\
\text { uring output } \\
\text { umber of sta } \\
\text { m quartile } \\
\text { denotes sig }\end{array}$ & $\begin{array}{l}\text { ariable sp } \\
\text { the regr } \\
\text { ar person } \\
\text { banks, n }\end{array}$ & $\begin{array}{l}\text { d by the coll } \\
\text { (See Table } \\
\text { ercent chang } \\
\text { of national } 1 \\
\text { banks denot }\end{array}$ & $\begin{array}{l}\text { mn titles. Ea } \\
\text { Census var } \\
\text { in crop outp } \\
\text { anks, and wh } \\
\text { s banks crea } \\
\text { el and } * * * \text { a }\end{array}$ & $\begin{array}{l}\text { h observatic } \\
\text { lables incluc } \\
\text { ut per perioc } \\
\text { ether a clear } \\
\text { ed after } 190\end{array}$ & $\begin{array}{l}\text { is a bank- } \\
\text { the } \\
\text { the } \\
\text { ghouse } \\
\text { Standard }\end{array}$ \\
\hline
\end{tabular}


Table 6: Effect of Deposit Insurance on Bank-Risk Measures at the Bank-Level (1900-1920)

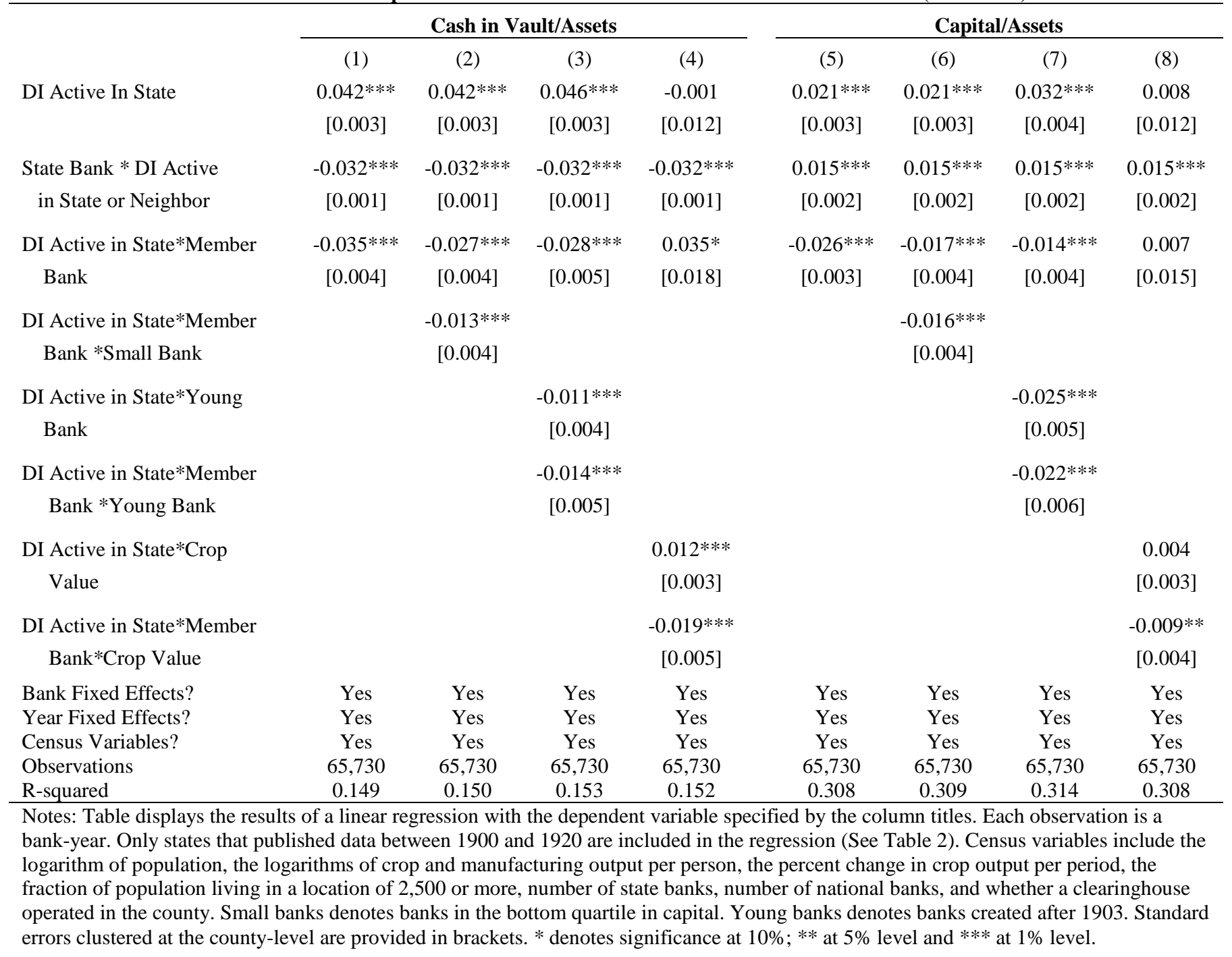


Table 7: Effect of Deposit Insurance on Banks Using Closest Neighbor Pairs (1900-1920)

\begin{tabular}{|c|c|c|c|c|}
\hline & \multicolumn{4}{|c|}{ Kansas State Banks Only } \\
\hline & $\begin{array}{c}\text { Ln(Deposits) } \\
\text { (1) }\end{array}$ & $\begin{array}{c}\text { Ln(Loans) } \\
\text { (2) }\end{array}$ & $\begin{array}{c}\text { Cash in } \\
\text { Vault/ Assets } \\
\text { (3) }\end{array}$ & $\begin{array}{c}\text { Capital/ } \\
\text { Assets } \\
(4)\end{array}$ \\
\hline DI Active in State & $0.120 * * *$ & $0.094 * *$ & -0.003 & $-0.015 * * *$ \\
\hline *Insured & {$[0.038]$} & {$[0.042]$} & {$[0.005]$} & {$[0.006]$} \\
\hline Bank Fixed Effects? & Yes & Yes & Yes & Yes \\
\hline Year Fixed Effects? & Yes & Yes & Yes & Yes \\
\hline Census Variables? & Yes & Yes & Yes & Yes \\
\hline Observations & 8,389 & 8,389 & 8,389 & 8,389 \\
\hline \multirow[t]{3}{*}{ R-squared } & 0.402 & 0.386 & 0.666 & 0.352 \\
\hline & \multicolumn{4}{|c|}{ Nebraska and Iowa } \\
\hline & $\begin{array}{c}\text { Ln(Deposits) } \\
\text { (1) }\end{array}$ & $\begin{array}{c}\text { Ln(Loans) } \\
\text { (2) }\end{array}$ & $\begin{array}{c}\text { Cash in } \\
\text { Vault/ Assets } \\
\text { (3) }\end{array}$ & $\begin{array}{c}\text { Capital/ } \\
\text { Assets } \\
(4)\end{array}$ \\
\hline \multirow[t]{2}{*}{ DI Active In State } & $-0.100 * * *$ & -0.016 & $0.007 * *$ & $0.013 * *$ \\
\hline & {$[0.035]$} & [0.033] & [0.003] & [0.005] \\
\hline State Bank * DI Active & $0.102 * * *$ & $0.141 * * *$ & $-0.040 * * *$ & -0.002 \\
\hline in State or Neighbor & {$[0.025]$} & {$[0.023]$} & {$[0.002]$} & {$[0.004]$} \\
\hline DI Active in State & $0.214^{* * *}$ & $0.157 * * *$ & $-0.020 * * *$ & -0.007 \\
\hline *Insured & [0.039] & {$[0.038]$} & {$[0.004]$} & [0.006] \\
\hline Bank Fixed Effects? & Yes & Yes & Yes & Yes \\
\hline Year Fixed Effects? & Yes & Yes & Yes & Yes \\
\hline Census Variables? & Yes & Yes & Yes & Yes \\
\hline Observations & 22,563 & 22,563 & 22,563 & 22,563 \\
\hline \multirow[t]{3}{*}{ R-squared } & 0.361 & 0.386 & 0.167 & 0.331 \\
\hline & \multicolumn{4}{|c|}{ South Dakota, Minnesota, and Montana } \\
\hline & $\begin{array}{c}\text { Ln(Deposits) } \\
(1)\end{array}$ & $\begin{array}{c}\text { Ln(Loans) } \\
(2)\end{array}$ & $\begin{array}{c}\text { Cash in } \\
\text { Vault/ Assets } \\
\text { (3) }\end{array}$ & $\begin{array}{c}\text { Capital/ } \\
\text { Assets } \\
(4)\end{array}$ \\
\hline \multirow[t]{2}{*}{ DI Active In State } & $-0.155^{* * *}$ & -0.055 & $0.041^{* * *}$ & $0.030 * * *$ \\
\hline & {$[0.043]$} & [0.039] & {$[0.006]$} & {$[0.007]$} \\
\hline State Bank * DI Active & 0.050 & $0.118 * * *$ & $-0.038 * * *$ & 0.006 \\
\hline in State or Neighbor & [0.032] & [0.024] & [0.002] & [0.005] \\
\hline DI Active in State & $0.353^{* * *}$ & $0.297 * * *$ & $-0.074 * * *$ & $-0.026 * * *$ \\
\hline *Insured & {$[0.043]$} & [0.039] & {$[0.006]$} & {$[0.006]$} \\
\hline Bank Fixed Effects? & Yes & Yes & Yes & Yes \\
\hline Year Fixed Effects? & Yes & Yes & Yes & Yes \\
\hline Census Variables? & Yes & Yes & Yes & Yes \\
\hline Observations & 17,229 & 17,229 & 17,229 & 17,229 \\
\hline R-squared & 0.438 & 0.378 & 0.247 & 0.363 \\
\hline
\end{tabular}

Notes: Table displays the results of a linear regression with the dependent variable specified by the column titles. Each observation is a bank-year. The column headings provide the specific sample of banks included. Census variables include the logarithm of population, the logarithms of crop and manufacturing output per person, the percent change in crop output per period, the fraction of population living in a location of 2,500 or more, number of state banks, number of national banks, and whether a clearinghouse operated in the county. Standard errors clustered at the county-level are provided in brackets. * denotes significance at $10 \%$; $* *$ at $5 \%$ level and $* * *$ at $1 \%$ level. 
Table 8: Timing of Deposit Insurance Effect on Banks (1900-1920)

\begin{tabular}{|c|c|c|c|c|c|c|c|c|c|c|c|c|}
\hline \multirow[b]{2}{*}{ DI Active in State For 1 Period } & \multicolumn{3}{|c|}{ Ln(Inaiviaual Deposits) } & \multicolumn{3}{|c|}{ LII(LOdIIs) } & \multicolumn{3}{|c|}{ Cash in Vauit/ Assets } & \multicolumn{3}{|c|}{ Capital/Assets } \\
\hline & $\begin{array}{c}(1) \\
-0.110^{* * *} \\
{[0.019]}\end{array}$ & $\begin{array}{c}(2) \\
-0.112^{* * *} \\
{[0.019]}\end{array}$ & $\begin{array}{c}(3) \\
-0.069 \\
{[0.072]}\end{array}$ & $\begin{array}{c}(4) \\
-0.063^{* * *} \\
{[0.016]}\end{array}$ & $\begin{array}{c}(5) \\
-0.064^{* * *} \\
{[0.016]}\end{array}$ & $\begin{array}{c}(6) \\
-0.087 \\
{[0.055]}\end{array}$ & $\begin{array}{c}(7) \\
-0.001 \\
{[0.002]}\end{array}$ & $\begin{array}{c}(8) \\
-0.001 \\
{[0.002]}\end{array}$ & $\begin{array}{c}(9) \\
-0.005 \\
{[0.009]}\end{array}$ & $\begin{array}{c}(10) \\
0.015^{* * *} \\
{[0.003]}\end{array}$ & $\begin{array}{c}(11) \\
0.015^{* * *} \\
{[0.003]}\end{array}$ & $\begin{array}{c}(12) \\
0.002 \\
{[0.012]}\end{array}$ \\
\hline DI Active in State For 2 Periods & $\begin{array}{c}-0.187 * * * \\
{[0.021]}\end{array}$ & $\begin{array}{c}-0.191 * * * \\
{[0.022]}\end{array}$ & $\begin{array}{c}-0.146 * * \\
{[0.074]}\end{array}$ & $\begin{array}{c}-0.082 * * * \\
{[0.019]}\end{array}$ & $\begin{array}{c}-0.084^{* * *} \\
{[0.019]}\end{array}$ & $\begin{array}{l}-0.106^{*} \\
{[0.056]}\end{array}$ & $\begin{array}{c}-0.010 * * * \\
{[0.002]}\end{array}$ & $\begin{array}{c}-0.010^{* * *} \\
{[0.002]}\end{array}$ & $\begin{array}{l}-0.013 \\
{[0.009]}\end{array}$ & $\begin{array}{c}0.030^{* * *} \\
{[0.004]}\end{array}$ & $\begin{array}{c}0.030 * * * \\
{[0.004]}\end{array}$ & $\begin{array}{c}0.017 \\
{[0.012]}\end{array}$ \\
\hline DI Active in State For 3 Periods & $\begin{array}{c}-0.173 * * * \\
{[0.026]}\end{array}$ & $\begin{array}{c}-0.216 * * * \\
{[0.030]}\end{array}$ & $\begin{array}{l}-0.129 \\
{[0.080]}\end{array}$ & $\begin{array}{c}-0.090 * * * \\
{[0.022]}\end{array}$ & $\begin{array}{c}-0.111^{* * *} \\
{[0.024]}\end{array}$ & $\begin{array}{l}-0.115^{*} \\
{[0.062]}\end{array}$ & $\begin{array}{c}-0.015^{* * *} \\
{[0.002]}\end{array}$ & $\begin{array}{c}-0.021 * * * \\
{[0.003]}\end{array}$ & $\begin{array}{c}-0.019 * * \\
{[0.009]}\end{array}$ & $\begin{array}{c}0.025^{* * *} \\
{[0.004]}\end{array}$ & $\begin{array}{c}0.031^{* * *} \\
{[0.005]}\end{array}$ & $\begin{array}{c}0.011 \\
{[0.013]}\end{array}$ \\
\hline DI Active in State For 4+ Periods & $\begin{array}{c}-0.094 * * * \\
{[0.023]}\end{array}$ & $\begin{array}{c}-0.167 * * * \\
{[0.028]}\end{array}$ & $\begin{array}{l}-0.050 \\
{[0.081]}\end{array}$ & $\begin{array}{l}-0.021 \\
{[0.023]}\end{array}$ & $\begin{array}{c}-0.059 * * \\
{[0.025]}\end{array}$ & $\begin{array}{l}-0.046 \\
{[0.064]}\end{array}$ & $\begin{array}{c}0.116^{* * *} \\
{[0.004]}\end{array}$ & $\begin{array}{c}0.094 * * * \\
{[0.004]}\end{array}$ & $\begin{array}{c}0.112^{* * *} \\
{[0.009]}\end{array}$ & $\begin{array}{c}0.018^{* * *} \\
{[0.004]}\end{array}$ & $\begin{array}{c}0.031^{* * *} \\
{[0.004]}\end{array}$ & $\begin{array}{c}0.004 \\
{[0.014]}\end{array}$ \\
\hline $\begin{array}{l}\text { State Bank * DI Active in State } \\
\text { or Neighbor }\end{array}$ & $\begin{array}{c}0.005 \\
{[0.012]}\end{array}$ & $\begin{array}{c}0.009 \\
{[0.012]}\end{array}$ & $\begin{array}{c}0.006 \\
{[0.012]}\end{array}$ & $\begin{array}{c}0.089 * * * \\
{[0.011]}\end{array}$ & $\begin{array}{c}0.091 * * * \\
{[0.011]}\end{array}$ & $\begin{array}{c}0.089 * * * \\
{[0.011]}\end{array}$ & $\begin{array}{c}-0.022 * * * \\
{[0.001]}\end{array}$ & $\begin{array}{c}-0.021 * * * \\
{[0.001]}\end{array}$ & $\begin{array}{c}-0.022 * * * \\
{[0.001]}\end{array}$ & $\begin{array}{c}0.014^{* * *} \\
{[0.002]}\end{array}$ & $\begin{array}{c}0.013 * * * \\
{[0.002]}\end{array}$ & $\begin{array}{c}0.014 * * * \\
{[0.002]}\end{array}$ \\
\hline $\begin{array}{l}\text { DI Active in State For } 1 \text { Period } \\
* \text { Member }\end{array}$ & $\begin{array}{c}0.164^{* * *} \\
{[0.022]}\end{array}$ & $\begin{array}{c}0.163^{* * *} \\
{[0.022]}\end{array}$ & $\begin{array}{c}0.018 \\
{[0.082]}\end{array}$ & $\begin{array}{c}0.125^{* * *} \\
{[0.022]}\end{array}$ & $\begin{array}{c}0.124^{* * *} \\
{[0.022]}\end{array}$ & $\begin{array}{c}0.039 \\
{[0.077]}\end{array}$ & $\begin{array}{c}-0.007 * * \\
{[0.003]}\end{array}$ & $\begin{array}{c}-0.009 * * * \\
{[0.003]}\end{array}$ & $\begin{array}{c}0.017 \\
{[0.015]}\end{array}$ & $\begin{array}{c}-0.012 * * * \\
{[0.004]}\end{array}$ & $\begin{array}{c}-0.011^{* * *} \\
{[0.004]}\end{array}$ & $\begin{array}{c}0.014 \\
{[0.014]}\end{array}$ \\
\hline $\begin{array}{l}\text { DI Active in State For } 2 \text { Periods } \\
\text { * Member }\end{array}$ & $\begin{array}{c}0.215^{* * *} \\
{[0.022]}\end{array}$ & $\begin{array}{c}0.212 * * * \\
{[0.022]}\end{array}$ & $\begin{array}{c}0.069 \\
{[0.084]}\end{array}$ & $\begin{array}{c}0.138^{* * *} \\
{[0.021]}\end{array}$ & $\begin{array}{c}0.136 * * * \\
{[0.021]}\end{array}$ & $\begin{array}{c}0.051 \\
{[0.079]}\end{array}$ & $\begin{array}{l}-0.001 \\
{[0.003]}\end{array}$ & $\begin{array}{l}-0.003 \\
{[0.003]}\end{array}$ & $\begin{array}{c}0.024 \\
{[0.015]}\end{array}$ & $\begin{array}{c}-0.021 * * * \\
{[0.004]}\end{array}$ & $\begin{array}{c}-0.020 * * * \\
{[0.004]}\end{array}$ & $\begin{array}{c}0.004 \\
{[0.015]}\end{array}$ \\
\hline $\begin{array}{l}\text { DI Active in State For } 3 \text { Periods } \\
{ }^{*} \text { Member }\end{array}$ & $\begin{array}{c}0.346^{* * *} \\
{[0.027]}\end{array}$ & $\begin{array}{c}0.318^{* * *} \\
{[0.029]}\end{array}$ & $\begin{array}{l}0.187 * * \\
{[0.090]}\end{array}$ & $\begin{array}{c}0.246 * * * \\
{[0.023]}\end{array}$ & $\begin{array}{c}0.229 * * * \\
{[0.026]}\end{array}$ & $\begin{array}{l}0.150^{*} \\
{[0.085]}\end{array}$ & $\begin{array}{c}0.001 \\
{[0.002]}\end{array}$ & $\begin{array}{c}-0.020^{* * *} \\
{[0.004]}\end{array}$ & $\begin{array}{l}0.028^{*} \\
{[0.016]}\end{array}$ & $\begin{array}{c}-0.038 * * * \\
{[0.004]}\end{array}$ & $\begin{array}{c}-0.030 * * * \\
{[0.005]}\end{array}$ & $\begin{array}{l}-0.011 \\
{[0.016]}\end{array}$ \\
\hline $\begin{array}{l}\text { DI Active in State For 4+ Periods } \\
{ }^{*} \text { Member }\end{array}$ & $\begin{array}{c}0.348^{* * *} \\
{[0.025]}\end{array}$ & $\begin{array}{c}0.353^{* * *} \\
{[0.026]}\end{array}$ & $\begin{array}{c}0.192^{* *} \\
{[0.094]}\end{array}$ & $\begin{array}{c}0.305^{* * *} \\
{[0.025]}\end{array}$ & $\begin{array}{c}0.307^{* * *} \\
{[0.027]}\end{array}$ & $\begin{array}{l}0.213^{* *} \\
{[0.089]}\end{array}$ & $\begin{array}{c}-0.082^{* * *} \\
{[0.007]}\end{array}$ & $\begin{array}{c}-0.085^{* * *} \\
{[0.007]}\end{array}$ & $\begin{array}{c}-0.056 * * * \\
{[0.018]}\end{array}$ & $\begin{array}{c}-0.025^{* * *} \\
{[0.004]}\end{array}$ & $\begin{array}{c}-0.024 * * * \\
{[0.004]}\end{array}$ & $\begin{array}{c}0.002 \\
{[0.016]}\end{array}$ \\
\hline DI Active in State * WWI Period & & $\begin{array}{c}0.116^{* * *} \\
{[0.019]}\end{array}$ & & & $\begin{array}{c}0.062 * * * \\
{[0.013]}\end{array}$ & & & $\begin{array}{c}0.043^{* * *} \\
{[0.003]}\end{array}$ & & & $\begin{array}{c}-0.023 * * * \\
{[0.002]}\end{array}$ & \\
\hline $\begin{array}{l}\text { DI Active in State * Member } \\
* \text { WWI Period }\end{array}$ & & $\begin{array}{c}0.008 \\
{[0.023]}\end{array}$ & & & $\begin{array}{c}0.000 \\
{[0.024]}\end{array}$ & & & $\begin{array}{c}-0.023^{* * *} \\
{[0.005]}\end{array}$ & & & $\begin{array}{c}0.006 \\
{[0.004]}\end{array}$ & \\
\hline DI Active in State * Crop Value & & & $\begin{array}{l}-0.012 \\
{[0.019]}\end{array}$ & & & $\begin{array}{c}0.007 \\
{[0.015]}\end{array}$ & & & $\begin{array}{c}0.001 \\
{[0.003]}\end{array}$ & & & $\begin{array}{c}0.004 \\
{[0.003]}\end{array}$ \\
\hline $\begin{array}{l}\text { DI Active in State * Member } \\
* \text { Crop Value }\end{array}$ & & & $\begin{array}{l}0.042^{*} \\
{[0.022]}\end{array}$ & & & $\begin{array}{c}0.025 \\
{[0.021]}\end{array}$ & & & $\begin{array}{l}-0.007^{*} \\
{[0.004]}\end{array}$ & & & $\begin{array}{l}-0.007^{*} \\
{[0.004]}\end{array}$ \\
\hline Bank Fixed Effects? & Yes & Yes & Yes & Yes & Yes & Yes & Yes & Yes & Yes & Yes & Yes & Yes \\
\hline Year Fixed Effects? & Yes & Yes & Yes & Yes & Yes & Yes & Yes & Yes & Yes & Yes & Yes & Yes \\
\hline Census Variables? & Yes & Yes & Yes & Yes & Yes & Yes & Yes & Yes & Yes & Yes & Yes & Yes \\
\hline Observations & 65,730 & 65,730 & 65,730 & 65,730 & 65,730 & 65,730 & 65,730 & 65,730 & 65,730 & 65,730 & 65,730 & 65,730 \\
\hline R-squared & 0.321 & 0.323 & 0.322 & 0.327 & 0.328 & 0.327 & 0.275 & 0.294 & 0.276 & 0.309 & 0.312 & 0.310 \\
\hline
\end{tabular}

Notes: Table displays the results of a linear regression with the dependent variable specified by the column titles. Each observation is a bank-year. Only states that published data between 1900 and 1920 are included in the regression (See Table 2). Census variables include the logarithm of population, the logarithms of crop and manufacturing output per person, the percent change in crop output per period, the fraction of population living in a location of 2,500 or more, number of state banks, number of national banks, and whether a clearinghouse operated in the county. "WWI period" denotes 1916 and 1918 . Standard errors clustered at the county-level are provided in brackets. * denotes significance at $10 \%$; ** at $5 \%$ level and $* * *$ at $1 \%$ level. 
Table 9: Forecasting Deposit Growth At State Banks Using Market Discipline Measures Using a Panel Regression (1900-1920)

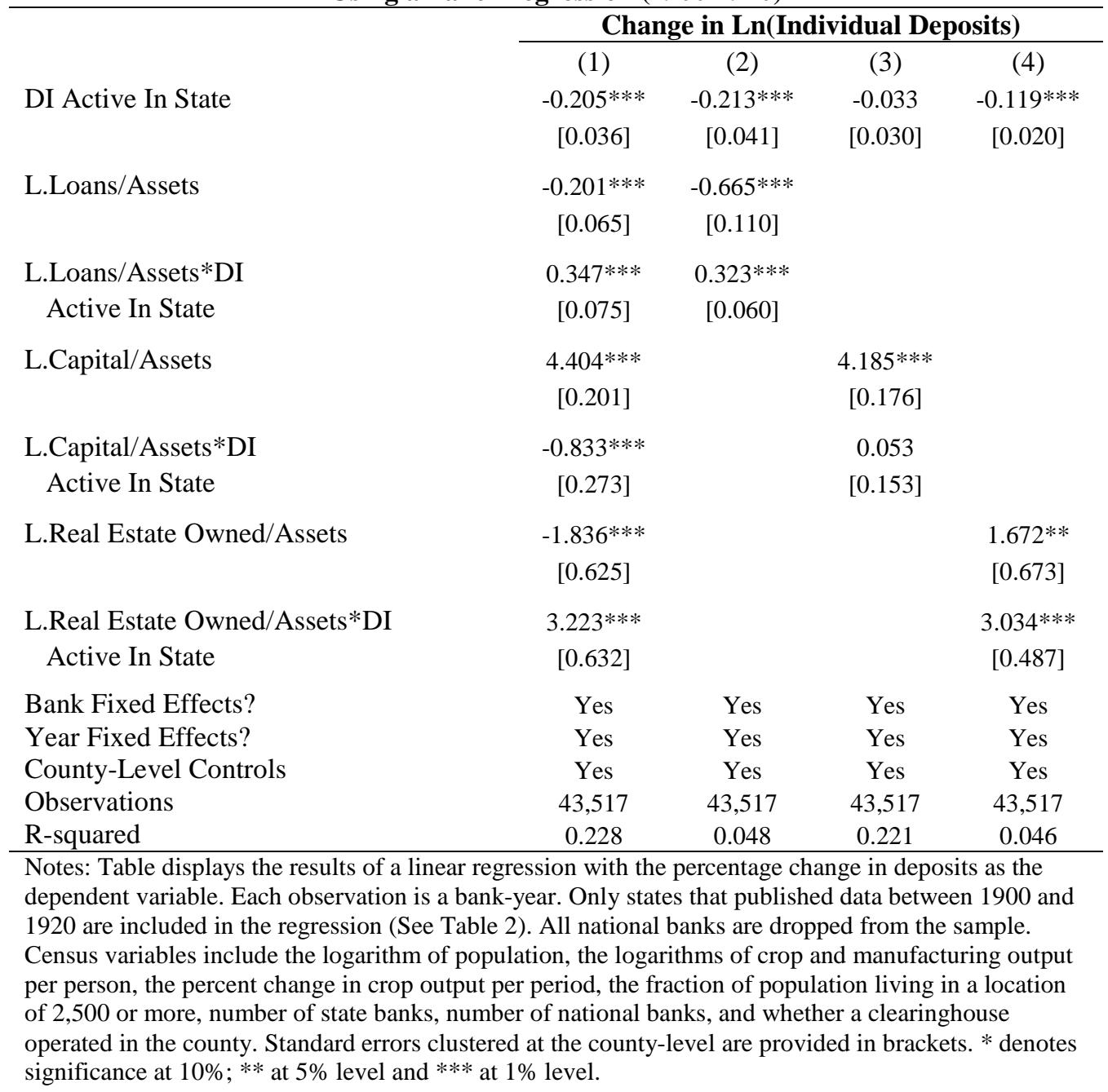


Table 10: Forecasting Deposit Growth At State Banks Using Market Discipline Measures Using Biennial Cross-Sections

\begin{tabular}{|c|c|c|c|c|c|c|c|c|c|}
\hline & \multicolumn{9}{|c|}{ Change in Ln(Individual Deposits) } \\
\hline & 1904 & 1906 & 1908 & 1910 & 1912 & 1914 & 1916 & 1918 & 1920 \\
\hline L.Loans/Assets & $\begin{array}{c}-0.669 * * * \\
{[0.128]}\end{array}$ & $\begin{array}{c}-0.573 * * * \\
{[0.090]}\end{array}$ & $\begin{array}{c}-0.487 * * * \\
{[0.087]}\end{array}$ & $\begin{array}{c}-0.319 * * * \\
{[0.087]}\end{array}$ & $\begin{array}{c}-0.640 * * * \\
{[0.071]}\end{array}$ & $\begin{array}{c}-0.364 * * * \\
{[0.070]}\end{array}$ & $\begin{array}{c}-1.227 * * * \\
{[0.080]}\end{array}$ & $\begin{array}{c}-0.356 * * * \\
{[0.058]}\end{array}$ & $\begin{array}{c}-0.063 \\
{[0.062]}\end{array}$ \\
\hline $\begin{array}{l}\text { L.Loans/Assets*DI } \\
\text { Active In State }\end{array}$ & & & & $\begin{array}{c}0.215 \\
{[0.146]}\end{array}$ & $\begin{array}{c}0.053 \\
{[0.075]}\end{array}$ & $\begin{array}{c}0.165 * * \\
{[0.077]}\end{array}$ & $\begin{array}{c}0.720 * * * \\
{[0.075]}\end{array}$ & $\begin{array}{c}0.317 * * * \\
{[0.064]}\end{array}$ & $\begin{array}{c}0.353 * * * \\
{[0.067]}\end{array}$ \\
\hline L.Capital/Assets & $\begin{array}{c}2.691 * * * \\
{[0.163]}\end{array}$ & $\begin{array}{c}2.677 * * * \\
{[0.131]}\end{array}$ & $\begin{array}{c}2.708 * * * \\
{[0.119]}\end{array}$ & $\begin{array}{c}2.389 * * * \\
{[0.120]}\end{array}$ & $\begin{array}{c}2.737 * * * \\
{[0.094]}\end{array}$ & $\begin{array}{c}1.901^{* * * *} \\
{[0.088]}\end{array}$ & $\begin{array}{c}4.138 * * * \\
{[0.086]}\end{array}$ & $\begin{array}{c}2.425 * * * \\
{[0.078]}\end{array}$ & $\begin{array}{c}3.264 * * * \\
{[0.095]}\end{array}$ \\
\hline $\begin{array}{l}\text { L.Capital/Assets*DI } \\
\text { Active In State }\end{array}$ & & & & $\begin{array}{l}-0.628 \\
{[0.474]}\end{array}$ & $\begin{array}{c}-0.133 \\
{[0.210]}\end{array}$ & $\begin{array}{c}-0.504^{* *} \\
{[0.219]}\end{array}$ & $\begin{array}{c}-2.562 * * * \\
{[0.199]}\end{array}$ & $\begin{array}{c}-0.801 * * * \\
{[0.215]}\end{array}$ & $\begin{array}{c}-1.828 * * * \\
{[0.261]}\end{array}$ \\
\hline L.Real Estate Owned/Assets & $\begin{array}{c}-0.956 * * \\
{[0.392]}\end{array}$ & $\begin{array}{c}-2.117 * * * \\
{[0.347]}\end{array}$ & $\begin{array}{c}-0.356 \\
{[0.312]}\end{array}$ & $\begin{array}{c}-0.298 \\
{[0.299]}\end{array}$ & $\begin{array}{c}-1.746 * * * \\
{[0.261]}\end{array}$ & $\begin{array}{c}-0.477 * * \\
{[0.216]}\end{array}$ & $\begin{array}{c}-5.083^{* * *} \\
{[0.207]}\end{array}$ & $\begin{array}{l}-0.389 * \\
{[0.218]}\end{array}$ & $\begin{array}{c}-0.017 \\
{[0.275]}\end{array}$ \\
\hline $\begin{array}{l}\text { L.Real Estate Owned/Assets*DI } \\
\text { Active In State }\end{array}$ & & & & $\begin{array}{c}1.649 \\
{[1.468]}\end{array}$ & $\begin{array}{c}0.575 \\
{[0.780]}\end{array}$ & $\begin{array}{c}0.980 \\
{[0.756]}\end{array}$ & $\begin{array}{c}6.175^{* * *} \\
{[0.521]}\end{array}$ & $\begin{array}{c}0.720 \\
{[0.584]}\end{array}$ & $\begin{array}{c}2.768 * * * \\
{[0.760]}\end{array}$ \\
\hline $\begin{array}{l}\text { Location Fixed Effects? } \\
\text { Year Fixed Effects? } \\
\text { County-Level Controls } \\
\text { Observations } \\
\text { R-squared }\end{array}$ & $\begin{array}{l}\text { State } \\
\text { No } \\
\text { Yes } \\
2,348 \\
0.166\end{array}$ & $\begin{array}{l}\text { State } \\
\text { No } \\
\text { Yes } \\
2,917 \\
0.180\end{array}$ & $\begin{array}{l}\text { State } \\
\text { No } \\
\text { Yes } \\
3,697 \\
0.184\end{array}$ & $\begin{array}{l}\text { State } \\
\text { No } \\
\text { Yes } \\
4,260 \\
0.148\end{array}$ & $\begin{array}{l}\text { State } \\
\text { No } \\
\text { Yes } \\
4,826 \\
0.243\end{array}$ & $\begin{array}{l}\text { State } \\
\text { No } \\
\text { Yes } \\
5,192 \\
0.155\end{array}$ & $\begin{array}{l}\text { State } \\
\text { No } \\
\text { Yes } \\
5,726 \\
0.391\end{array}$ & $\begin{array}{l}\text { State } \\
\text { No } \\
\text { Yes } \\
6,072 \\
0.208\end{array}$ & $\begin{array}{l}\text { State } \\
\text { No } \\
\text { Yes } \\
6,571 \\
0.254\end{array}$ \\
\hline $\begin{array}{l}\text { Notes: Table displays the results } \\
\text { Each observation is a bank-year. } \\
\text { are dropped from the sample. Cen } \\
\text { percent change in crop output per } \\
\text { banks, and whether a clearinghou } \\
\text { at } 10 \% \text {; ** at } 5 \% \text { level and } * * * \text { at }\end{array}$ & $\begin{array}{l}\text { ndividual y } \\
\text { ly states the } \\
\text { s variables } \\
\text { riod, the fr } \\
\text { operated in } \\
\text { \% level. }\end{array}$ & $\begin{array}{l}\text { ar linear cr } \\
\text { published } \\
\text { clude the l } \\
\text { tion of pop } \\
\text { le county. }\end{array}$ & $\begin{array}{l}\text {-sectional } \mathrm{r} \\
\text { a between } \\
\text { rithm of p } \\
\text { tion living } \\
\text { adard error }\end{array}$ & $\begin{array}{l}\text { gressions w } \\
900 \text { and } 192 \\
\text { pulation, the } \\
\text { n a location } \\
\text { clustered at }\end{array}$ & $\begin{array}{l}\text { the perce } \\
\text { are include } \\
\text { garithms } \\
2,500 \text { or r } \\
\text { e county-l }\end{array}$ & $\begin{array}{l}\text { ge change } \\
\text { n the regre } \\
\text { rop and m } \\
\text { re, number } \\
\text { el are prov }\end{array}$ & $\begin{array}{l}\text { deposits as } \\
\text { on (See Ta } \\
\text { dfacturing } \\
\text { state bank } \\
\text { d in bracke }\end{array}$ & $\begin{array}{l}\text { e dependent } \\
2 \text { ). All nat } \\
\text { put per pers } \\
\text { humber of } n \\
* \text { denotes } s\end{array}$ & $\begin{array}{l}\text { variable. } \\
\text { nal banks } \\
\text { n, the } \\
\text { tional } \\
\text { gnificance }\end{array}$ \\
\hline
\end{tabular}


Table 11: Forecasting Deposit Growth At State Banks Using Market Discipline Measures By State

Voluntary DI Active In State

Involuntary DI Active In NE

Involuntary DI Active In SD

L.Loans/Assets

L.Loans/Assets* Voluntary DI

Member in KS * DI Active

L.Loans/Assets* Involuntary DI

Member in NE * DI Active

L.Loans/Assets* Involuntary DI

Member in SD * DI Active

L.Capital/Assets

L.Capital/Assets* Voluntary D

Member in KS * DI Active

L.Capital/Assets* Involuntary DI

Member in NE* DI Active

L.Capital/Assets* Involuntary DI

Member in SD * DI Active

L.Real Estate Owned/Assets

L.Real Estate Owned* Voluntary D

Member in KS* DI Active

L.Real Estate Owned* Involuntary DI

Member in NE* DI Active

L.Real Estate Owned* Involuntary DI

Member in SD * DI Active

Location Fixed Effects?

Year Fixed Effects?

County-Level Controls

Observations

R-squared

1920 displays the results of a linear regression with the percentage change in deposits as the dependent variable. Each observation is a bank-year. Only states that published data between 1900

\begin{tabular}{|c|c|c|c|c|c|c|c|c|c|}
\hline \\
\hline $1900-1920$ & 1904 & 1906 & 1908 & 1910 & 1912 & 1914 & 1916 & 1918 & 1920 \\
\hline $\begin{array}{c}-0.189^{* * *} \\
{[0.040]}\end{array}$ & & & & & & & & & \\
\hline $\begin{array}{c}-0.492 * * * \\
{[0.084]}\end{array}$ & & & & & & & & & \\
\hline $\begin{array}{l}-0.077 \\
{[0.111]}\end{array}$ & & & & & & & & & \\
\hline $\begin{array}{c}-0.207 * * * \\
{[0.067]}\end{array}$ & $\begin{array}{c}-0.669 * * * \\
{[0.128]}\end{array}$ & $\begin{array}{c}-0.573 * * * \\
{[0.090]}\end{array}$ & $\begin{array}{c}-0.487 * * * \\
{[0.087]}\end{array}$ & $\begin{array}{c}-0.315^{* * *} \\
{[0.087]}\end{array}$ & $\begin{array}{c}-0.656 * * * \\
{[0.073]}\end{array}$ & $\begin{array}{c}-0.352 * * * \\
{[0.073]}\end{array}$ & $\begin{array}{c}-1.311 * * * \\
{[0.084]}\end{array}$ & $\begin{array}{c}-0.412^{* * *} \\
{[0.063]}\end{array}$ & $\begin{array}{l}-0.064 \\
{[0.065]}\end{array}$ \\
\hline $\begin{array}{l}0.296 * \\
{[0.161]}\end{array}$ & & & & $\begin{array}{c}0.206 \\
{[0.146]}\end{array}$ & $\begin{array}{c}-0.175^{*} \\
{[0.095]}\end{array}$ & $\begin{array}{c}0.552^{* * *} \\
{[0.134]}\end{array}$ & $\begin{array}{c}0.701^{* * *} \\
{[0.119]}\end{array}$ & $\begin{array}{c}0.632^{* * *} \\
{[0.113]}\end{array}$ & $\begin{array}{c}0.438 * * * \\
{[0.119]}\end{array}$ \\
\hline $\begin{array}{c}0.613^{* * *} \\
{[0.117]}\end{array}$ & & & & & $\begin{array}{l}0.421^{*} \\
{[0.244]}\end{array}$ & $\begin{array}{c}0.099 \\
{[0.224]}\end{array}$ & $\begin{array}{c}1.520 * * * \\
{[0.285]}\end{array}$ & $\begin{array}{c}0.677 * * * \\
{[0.173]}\end{array}$ & $\begin{array}{c}0.422^{* *} \\
{[0.196]}\end{array}$ \\
\hline $\begin{array}{l}0.291 * \\
{[0.155]}\end{array}$ & & & & & & & $\begin{array}{c}0.962^{* *} \\
{[0.414]}\end{array}$ & $\begin{array}{l}0.467 * \\
{[0.261]}\end{array}$ & $\begin{array}{c}0.223 \\
{[0.347]}\end{array}$ \\
\hline $\begin{array}{c}4.368 * * * \\
{[0.198]}\end{array}$ & $\begin{array}{c}2.691 * * * \\
{[0.163]}\end{array}$ & $\begin{array}{c}2.677 * * * \\
{[0.131]}\end{array}$ & $\begin{array}{c}2.708^{* * *} \\
{[0.119]}\end{array}$ & $\begin{array}{c}2.357 * * * \\
{[0.120]}\end{array}$ & $\begin{array}{c}2.712 * * * \\
{[0.094]}\end{array}$ & $\begin{array}{c}1.842^{* * *} \\
{[0.087]}\end{array}$ & $\begin{array}{c}4.024 * * * \\
{[0.087]}\end{array}$ & $\begin{array}{c}2.380 * * * \\
{[0.077]}\end{array}$ & $\begin{array}{c}3.234 * * * \\
{[0.095]}\end{array}$ \\
\hline $\begin{array}{c}-0.871 \\
{[0.631]}\end{array}$ & & & & $\begin{array}{c}-0.602 \\
{[0.474]}\end{array}$ & $\begin{array}{c}1.043^{* * *} \\
{[0.286]}\end{array}$ & $\begin{array}{c}-1.579 * * * \\
{[0.424]}\end{array}$ & $\begin{array}{c}-2.506 * * * \\
{[0.369]}\end{array}$ & $\begin{array}{c}-2.168 * * * \\
{[0.424]}\end{array}$ & $\begin{array}{c}-2.310 * * * \\
{[0.587]}\end{array}$ \\
\hline $\begin{array}{c}-0.474 * \\
{[0.249]}\end{array}$ & & & & & $\begin{array}{c}-1.165 * * * \\
{[0.307]}\end{array}$ & $\begin{array}{l}-0.163 \\
{[0.279]}\end{array}$ & $\begin{array}{c}-2.242 * * * \\
{[0.297]}\end{array}$ & $\begin{array}{l}-0.099 \\
{[0.316]}\end{array}$ & $\begin{array}{c}-1.706^{* * *} \\
{[0.353]}\end{array}$ \\
\hline $\begin{array}{c}-0.845 * * * \\
{[0.254]}\end{array}$ & & & & & & & $\begin{array}{c}-2.271 * * * \\
{[0.396]}\end{array}$ & $\begin{array}{c}-0.532 \\
{[0.414]}\end{array}$ & $\begin{array}{c}-1.728 * * * \\
{[0.497]}\end{array}$ \\
\hline $\begin{array}{c}-1.759 * * * \\
{[0.628]}\end{array}$ & $\begin{array}{c}-0.956 * * \\
{[0.392]}\end{array}$ & $\begin{array}{c}-2.117 * * * \\
{[0.347]}\end{array}$ & $\begin{array}{l}-0.356 \\
{[0.312]}\end{array}$ & $\begin{array}{l}-0.305 \\
{[0.300]}\end{array}$ & $\begin{array}{c}-1.743 * * * \\
{[0.261]}\end{array}$ & $\begin{array}{c}-0.407 * \\
{[0.216]}\end{array}$ & $\begin{array}{c}-5.114 * * * \\
{[0.209]}\end{array}$ & $\begin{array}{c}-0.401 * \\
{[0.217]}\end{array}$ & $\begin{array}{c}0.022 \\
{[0.275]}\end{array}$ \\
\hline $\begin{array}{c}1.209 \\
{[1.469]}\end{array}$ & & & & $\begin{array}{c}1.654 \\
{[1.469]}\end{array}$ & $\begin{array}{c}-2.508 * * \\
{[1.118]}\end{array}$ & $\begin{array}{c}0.618 \\
{[1.160]}\end{array}$ & $\begin{array}{c}5.681^{* * *} \\
{[0.994]}\end{array}$ & $\begin{array}{c}1.018 \\
{[1.070]}\end{array}$ & $\begin{array}{c}2.946^{* *} \\
{[1.362]}\end{array}$ \\
\hline $\begin{array}{c}4.224 * * * \\
{[0.816]}\end{array}$ & & & & & $\begin{array}{c}3.707 * * * \\
{[1.042]}\end{array}$ & $\begin{array}{c}1.344 \\
{[0.967]}\end{array}$ & $\begin{array}{c}7.030 * * * \\
{[1.049]}\end{array}$ & $\begin{array}{c}2.118^{* *} \\
{[1.073]}\end{array}$ & $\begin{array}{c}3.512 * * * \\
{[1.196]}\end{array}$ \\
\hline $\begin{array}{c}2.789 * * * \\
{[0.580]}\end{array}$ & & & & & & & $\begin{array}{c}6.260^{* * *} \\
{[0.787]}\end{array}$ & $\begin{array}{c}0.013 \\
{[0.862]}\end{array}$ & $\begin{array}{c}1.762 \\
{[1.258]}\end{array}$ \\
\hline Bank & State & State & State & State & State & State & State & State & State \\
\hline $\begin{array}{l}\text { Yes } \\
\text { Yes }\end{array}$ & $\begin{array}{l}\text { No } \\
\text { Yes }\end{array}$ & $\begin{array}{l}\text { No } \\
\text { Yes }\end{array}$ & $\begin{array}{l}\text { No } \\
\text { Yes }\end{array}$ & $\begin{array}{l}\text { No } \\
\text { Yes }\end{array}$ & $\begin{array}{l}\text { No } \\
\text { Yes }\end{array}$ & $\begin{array}{l}\text { No } \\
\text { Yes }\end{array}$ & $\begin{array}{l}\text { No } \\
\text { Yes }\end{array}$ & $\begin{array}{l}\text { No } \\
\text { Yes }\end{array}$ & $\begin{array}{l}\text { No } \\
\text { Yes }\end{array}$ \\
\hline 43,517 & 2,348 & 2,917 & 3,697 & 4,260 & 4,826 & 5,192 & 5,726 & 6,072 & 6,571 \\
\hline 0.229 & 0.166 & 0.180 & 0.184 & 0.146 & 0.248 & 0.155 & 0.388 & 0.215 & 0.256 \\
\hline
\end{tabular}

Change in Ln(Individual Deposits) 
Table 12: Conversion of State Banks to National Banks By State (1908-1929)

\begin{tabular}{|c|c|c|c|c|c|c|c|c|}
\hline & \multicolumn{2}{|c|}{ Conversions 1908-1920 } & \multicolumn{2}{|c|}{ Conversions 1920-1929 } & \multicolumn{2}{|c|}{$\begin{array}{c}\text { Ratio of Converted Bank } \\
\text { Capital to Average Bank } \\
\text { Capital }\end{array}$} & \multicolumn{2}{|c|}{$\%$ of Banks } \\
\hline & Number & Capital & Number & Capital & 1908-1920 & 1920-1929 & 1908-1920 & $1920-1929$ \\
\hline Kansas & 16 & 655,000 & 12 & $1,155,000$ & $194.8 \%$ & $363.4 \%$ & $1.7 \%$ & $1.2 \%$ \\
\hline Mississippi & 6 & 350,000 & 8 & 875,000 & $144.1 \%$ & $268.6 \%$ & $2.1 \%$ & $2.7 \%$ \\
\hline Nebraska & 28 & $1,300,000$ & 12 & 715,000 & $210.1 \%$ & $203.9 \%$ & $3.5 \%$ & $1.3 \%$ \\
\hline North Dakota & 50 & $1,650,000$ & 7 & 325,000 & $221.4 \%$ & $211.8 \%$ & $8.3 \%$ & $1.4 \%$ \\
\hline Oklahoma & 63 & $2,545,000$ & 85 & $4,100,000$ & $242.9 \%$ & $222.9 \%$ & $10.7 \%$ & $20.5 \%$ \\
\hline Texas & 30 & $1,792,500$ & 110 & $8,250,000$ & $196.6 \%$ & $182.3 \%$ & $3.3 \%$ & $11.4 \%$ \\
\hline Washington & 33 & $3,480,000$ & 28 & $2,420,000$ & $204.8 \%$ & $169.8 \%$ & $11.9 \%$ & $10.7 \%$ \\
\hline DI States & 251 & $12,747,500$ & 264 & $17,890,000$ & $206.9 \%$ & $216.4 \%$ & $5.1 \%$ & $5.5 \%$ \\
\hline Arkansas & 22 & $1,122,500$ & 5 & 300,000 & $145.1 \%$ & $145.0 \%$ & $5.7 \%$ & $1.3 \%$ \\
\hline Colorado & 17 & $1,045,000$ & 5 & 675,000 & $184.7 \%$ & $371.1 \%$ & $8.4 \%$ & $2.5 \%$ \\
\hline Iowa & 12 & 470,000 & 2 & 290,000 & $119.6 \%$ & $364.5 \%$ & $0.9 \%$ & $0.1 \%$ \\
\hline Louisiana & 5 & 800,000 & 0 & 0 & $219.4 \%$ & & $2.4 \%$ & \\
\hline Missouri & 15 & $4,635,000$ & 9 & $3,012,500$ & $717.1 \%$ & $611.8 \%$ & $1.2 \%$ & $0.6 \%$ \\
\hline Montana & 31 & $1,205,000$ & 0 & 0 & $105.3 \%$ & & $15.4 \%$ & \\
\hline New Mexico & 3 & 200,000 & 1 & 50,000 & $191.7 \%$ & $122.4 \%$ & $5.8 \%$ & $2.3 \%$ \\
\hline Wyoming & 7 & 220,000 & 0 & 0 & $132.5 \%$ & & $9.4 \%$ & \\
\hline Non-DI Comparison States & 167 & $13,267,500$ & 33 & $5,357,500$ & $231.9 \%$ & $321.7 \%$ & $3.6 \%$ & $0.7 \%$ \\
\hline $\begin{array}{l}\text { Non-DI Comparison States } \\
\text { Without MO }\end{array}$ & 152 & $8,632,500$ & 24 & $2,345,000$ & $171.3 \%$ & $263.7 \%$ & $4.4 \%$ & $0.6 \%$ \\
\hline
\end{tabular}

Notes: Table provides the number of state bank conversions to a national bank charter and their aggregate capital between the supplied dates. The data come from the Office of the Comptroller of the Currency $(1907,1920,1929)$. 